\title{
Genetic Deletion of Trace Amine 1 Receptors Reveals Their Role in Auto-Inhibiting the Actions of Ecstasy (MDMA)
}

\author{
Benjamin Di Cara, ${ }^{1}$ Roberto Maggio, ${ }^{5}$ Gabriella Aloisi, ${ }^{5}$ Jean-Michel Rivet, ${ }^{1}$ Ebba Gregorsson Lundius, ${ }^{6}$ \\ Takashi Yoshitake, ${ }^{6}$ Per Svenningsson, ${ }^{6}$ Mauricette Brocco,${ }^{1}$ Alain Gobert, ${ }^{1}$ Lotte De Groote, ${ }^{1}$ Laetitia Cistarelli, ${ }^{1}$ \\ Sylvie Veiga, ${ }^{1}$ Catherine De Montrion, ${ }^{2}$ Marianne Rodriguez, ${ }^{2}$ Jean-Pierre Galizzi, ${ }^{2}$ Brian P. Lockhart, ${ }^{2}$ Francis Cogé, ${ }^{3}$ \\ Jean A. Boutin, ${ }^{3}$ Philippe Vayer, ${ }^{4}$ P. Monika Verdouw, ${ }^{7}$ Lucianne Groenink, ${ }^{7}$ and Mark J. Millan ${ }^{1}$ \\ Departments of ${ }^{1}$ Neurobiology, ${ }^{2}$ Molecular Pharmacology and Pathophysiology, ${ }^{3}$ Biotechnology and Cellular-Molecular Pharmacology, and \\ ${ }^{4}$ Biopharmaceutical Research, Institut de Recherches Servier, 78290 Croissy-sur-Seine, France, ${ }^{5}$ Department of Experimental Medicine, University of \\ L'Aquila, L-7100 L'Aquila, Italy, ${ }^{6}$ Department of Clinical Neuroscience, Karolinska Institute, SE-171 77 Stockholm, Sweden, and Division of Pharmacology, \\ Utrecht Institute for Pharmaceutical Sciences, 3584 Utrecht, The Netherlands
}

\begin{abstract}
"Ecstasy" [3,4-methylenedioxymetamphetamine (MDMA)] is of considerable interest in light of its prosocial properties and risks associated with widespread recreational use. Recently, it was found to bind trace amine-1 receptors $\left(\mathrm{TA}_{1} \mathrm{Rs}\right)$, which modulate dopaminergic transmission. Accordingly, using mice genetically deprived of $\mathrm{TA}_{1} \mathrm{R}\left(T A_{1}-K O\right)$, we explored their significance to the actions of MDMA, which robustly activated human adenylyl cyclase-coupled $\mathrm{TA}_{1} \mathrm{R}$ transfected into HeLa cells. In wild-type (WT) mice, MDMA elicited a time-, dose-, and ambient temperature-dependent hypothermia and hyperthermia, whereas $T A_{1}-K O$ mice displayed hyperthermia only. MDMA-induced increases in dialysate levels of dopamine (DA) in dorsal striatum were amplified in $T A_{1}-K O$ mice, despite identical levels of MDMA itself. A similar facilitation of the influence of MDMA upon dopaminergic transmission was acquired in frontal cortex and nucleus accumbens, and induction of locomotion by MDMA was haloperidol-reversibly potentiated in $T A_{1}-K O$ versus WT mice. Conversely, genetic deletion of $\mathrm{TA}_{1} \mathrm{R}$ did not affect increases in DA levels evoked by para-chloroamphetamine (PCA), which was inactive at $\mathrm{hTA}_{1}$ sites. The $\mathrm{TA}_{1} \mathrm{R}$ agonist $o$-phenyl-3-iodotyramine (o-PIT) blunted the DA-releasing actions of PCA both in vivo (dialysis) and in vitro (synaptosomes) in WT but not $T A_{1}-K O$ animals. MDMA-elicited increases in dialysis levels of serotonin (5-HT) were likewise greater in $T A_{1}-\mathrm{KO}$ versus WT mice, and 5-HT-releasing actions of PCA were blunted in vivo and in vitro by $o$-PIT in WT mice only. In conclusion, $\mathrm{TA}_{1}$ Rs exert an inhibitory influence on both dopaminergic and serotonergic transmission, and MDMA auto-inhibits its neurochemical and functional actions by recruitment of $\mathrm{TA}_{1} \mathrm{R}$. These observations have important implications for the effects of MDMA in humans.
\end{abstract}

\section{Introduction}

The monoamine releaser and reuptake suppressor, "ecstasy" [3,4-methylenedioxymetamphetamine (MDMA)], facilitates prosocial behaviors in animals and humans (Bedi et al., 2009; Johansen and Krebs, 2009), actions related to enhanced release of oxytocin in centers controlling social behavior, like amygdala and septum (McGregor et al., 2008). However, greater attention has been devoted to the psychostimulant properties of MDMA and its widespread recreational use (Vollenweider et al., 1999, 2002). In addition, MDMA can trigger a serotonergic syndrome and disrupt thermoregulatory mechanisms, neurotoxic effects especially prominent in young adults under conditions of dehydration (Schifano, 2004; Baumann et al., 2007; Karlsen et al., 2008).

Received May 18, 2011; revised Sept. 8, 2011; accepted Sept. 10, 2011.

Author contributions: B.D.C., R.M., J.-M.R., P.S., M.B., A.G., L.D.G., C.D.M., M.R., J.-P.G., B.P.L., F.C., J.A.B., P.V., L.G., and M.J.M. designed research; G.A., E.G.L., T.Y., L.C., S.V., and P.M.V. performed research; B.D.C., R.M., and P.S. analyzed data; B.D.C., R.M., P.S., and M.J.M. wrote the paper.

The authors declare no competing financial interests.

Correspondence should be addressed to Mark J. Millan, Institut de Recherche Servier, Department of Neurobiology, 125, Chemin de Ronde, 78290 Croissy-sur-Seine, France. E-mail: mark.millan@fr.netgrs.com.

DOI:10.1523/JNEUROSCI.2502-11.2011

Copyright $\odot 2011$ the authors $\quad 0270-6474 / 11 / 3116928-13 \$ 15.00 / 0$
It is thus important to elucidate the precise mechanisms of action of MDMA.

MDMA displaces neuronal serotonin (5-HT) via reversal of vesicular and plasma membrane transporters (Rudnick and Wall, 1992; Mlinar and Corradetti, 2003). Further, it prevents 5-HT reuptake (Iravani et al., 2000) and inhibits the activity of the catabolytic enzyme monoamine oxidase A (Leonardi and Azmitia, 1994). Concomitant elevations in dopamine (DA) and noradrenaline (NA) levels occur either via a similar pattern of direct actions upon catecholaminergic pathways (Gough et al., 2002; Baumann et al., 2005, 2008) and/or events downstream of serotonergic transmission, such as activation of $5-\mathrm{HT}_{2 \mathrm{~A}}$ receptors (Gobert et al., 2000). Moreover, at high concentrations, MDMA binds to $5-\mathrm{HT}_{2 \mathrm{~A}}$, histamine $\mathrm{H}_{1}$, and muscarinic $\mathrm{M}_{1} / \mathrm{M}_{2}$ receptors, though their putative roles in its functional actions remain poorly characterized (Green et al., 2003).

A potentially novel dimension to the neurobiology of MDMA was unveiled by the suggestion that it recognizes Gs-coupled TA receptors $\left[\mathrm{TA}_{1} \mathrm{Rs}\right.$ (sometimes called $\mathrm{TAAR}_{1} \mathrm{~s}$ )] (Bunzow et al., 2001; Lindemann and Hoener, 2005; Maguire et al., 2009). While most subtypes of trace amine (TA) receptor are preferentially expressed in olfactory epithelium (Liberles and Buck, 2006), 
A
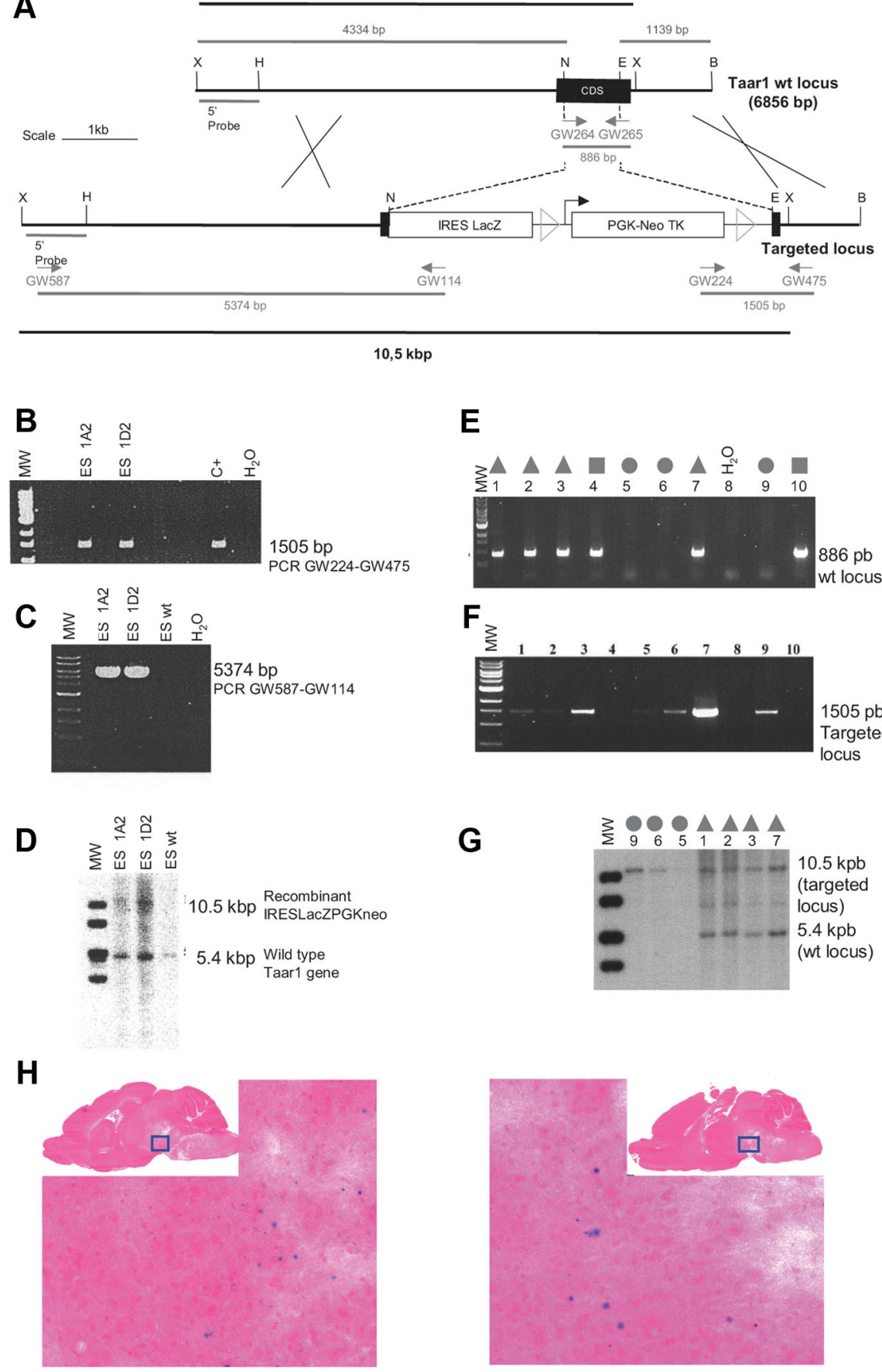

G

E
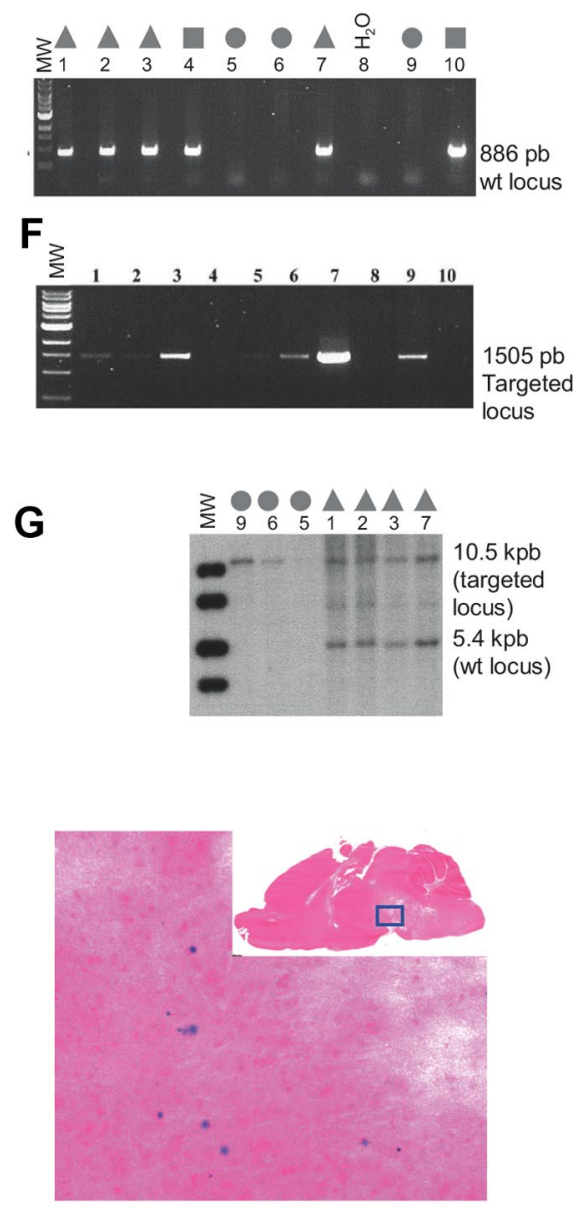

Figure 1. Generation of $\mathrm{TA}_{1} \mathrm{R}^{-1-}$ knock-out mice. $\boldsymbol{A}$, Strategy for targeted deletion of the Taar 1 gene in mouse ES cells. The Taar 1 coding sequence was partially replaced by a cDNA encoding IRES-LacZ-NeoTk cassette. The IRES-LacZ-Neo was fused in frame with the endogenous Taar1 start codon. B, Bglll site; E, EcoRI site; H, HindIII site; N, Nsil site; S, Spel site; X, Xbal site; CDS, coding domain sequence of unique exon of Taar1 gene. The arrowhead corresponds to the loxP sites. B, C, PCR screening on the $3^{\prime}(\boldsymbol{B})$ and $5^{\prime}(\boldsymbol{C})$ end of homologous recombination event. The 1505 bp (primers GW224/GW475 corresponding to PGKneo-Taar 1 locus) and 5374 bp (primers GW587/GW114 corresponding to Taar 1 locus-IRES/LacZ) bands identified appropriated targeted disruption of murine mTaar 1 locus on $3^{\prime}$ and $5^{\prime}$ end-targeting events, respectively. The PCR screening on the $5^{\prime}$ and $3^{\prime}$ ends of the homologous recombination event is shown for ES cell clones $1 A 2$ and 1D2. M, NEB Biolabs 1 kbp DNA ladder; $C+$, genomic DNA from ES cell clone transfected with positive vector. $\boldsymbol{D}$, Southern blot analysis of positive and wild-type ES cell clones. Digestion of genomic DNA with Xbal resulted in the following fragments: wild-type allele of $5.4 \mathrm{~kb}$ band, appropriate targeting of the Taar 1 locus of $10.5 \mathrm{~kb}$ band. $\boldsymbol{E}, \boldsymbol{F}, \mathrm{PCR}$ screening analysis of the offspring of Taar1-mutated mice. Heterozygous and homozygous F2 mice were discriminate from wild type by PCR using couple primers specific for targeted (GW224/GW475, 1505 bp band, $\boldsymbol{E}$ ) and wild-type allele (GW264/ GW265, 886 bp band, $\boldsymbol{F})$. G, Southern blot analysis of the offspring of Taar1-mutated mice. Southern blot was performed on Xbal-digested genomic DNA using an Xbal/Hindlll probe specific for targeted region. The wild-type allele corresponds to a $5.4 \mathrm{~kb}$ band, and the appropriate targeting of the Taar 1 locus to a $10.5 \mathrm{~kb}$ band. A nonspecific background signal due to the $5^{\prime}$ probe used, was observed $\sim 7 \mathrm{~kb}$ for all of the samples analyzed. In $\boldsymbol{E}$ and $\boldsymbol{G}$, wild type is depicted by square, heterozygous by triangle, and
$\mathrm{TA}_{1} \mathrm{Rs}$ are mainly distributed in limbic structures and regions containing monoaminergic perykarias (Borowsky et al., 2001; Wolinsky et al., 2007; Lindemann et al., 2008). The TAs, tyramine, tryptamine, and $\beta$-phenethylamine are implicated in psychiatric and neurological disorders associated with monoaminergic dysfunction (Branchek and Blackburn, 2003; Berry, 2004; Burchett and Hicks, 2006; Sotnikova et al., 2008), yet it remains unproven that they act via $\mathrm{TA}_{1} \mathrm{Rs}$ in vivo. Conversely, the thyroxine derivatives 3-iodothyronamine ( $\left.\mathrm{T}_{1} \mathrm{AM}\right)$ and $o$-phenyl-3iodotyramine (o-PIT) behave as agonists at $\mathrm{TA}_{1} \mathrm{Rs}$, and their hypothermic actions are blunted in $\mathrm{TA}_{1}$ knock-out $\left(T A_{1}-K O\right)$ mice (Scanlan et al., 2004; Hart et al., 2006; Doyle et al., 2007) (M.J. Millan, unpublished observations).

Likewise of pertinence to MDMA, $\mathrm{TA}_{1}$ Rs inhibit the electrical and synthetic activity of nigrostriatal dopaminergic neurons (Geracitano et al., 2004; Lindemann et al., 2008; Bradaia et al., 2009; Ledonne et al., 2010). Moreover, functional interactions have been reported between colocalized $\mathrm{TA}_{1} \mathrm{R}$ and $\mathrm{DA}$ transporters (Xie and Miller, 2008; Xie et al., 2008). Interestingly, $\mathrm{T}_{1} \mathrm{AM}$ and $o$-PIT suppress locomotor activity in mice (Scanlan et al., 2004), actions opposite to those of MDMA (Baumann et al., 2008).

Collectively, these observations raise the intriguing possibility that $\mathrm{TA}_{1} \mathrm{R}$ may modulate the actions of MDMA. Though EPPTB (N-(3-ethoxy-phenyl)-4-pyrrolidin-1-yl-3-trifluoromethyl-benzamide) was described as a selective $T_{1} R$ antagonist (Bradaia et al., 2009; Stalder et al., 2011), it is not centrally active upon systemic administration. The present study addressed the role of $\mathrm{TA}_{1} \mathrm{R}$ in the physiological, neurochemi$\mathrm{cal}$, and behavioral actions of MDMA by exploiting $T A_{1}-K O$ mice.

\section{Materials and Methods}

Construction of the targeting vector. Targeting vector construction and knockout strategy have been designed and performed by genOway. Genomic clones containing the murine Taarl locus were isolated from a 129S6/ SvEvTacRPCI-22 bacterial artificial chromosome (BAC) genomic library using a probe corresponding to the murine Taar1 (nucleotides 45-950, GenBank accession \#AF380187). Two BAC clones (37K19 and 393O10) con-

homozygous by disc. MW, Molecular weight. $\boldsymbol{H}$, Sagittal sections illustrating the histoenzymological staining of $\beta$-galactosidase in the substantia nigra (left) and ventral tegmental area (right) of $T A_{1}-K O$ mice. 
Table 1. Relative $m R N A$ expression of $T A_{1} R$ and markers associated with corticolimbic dopaminergic systems in $W T$ and $T A_{7}-K O$ mice

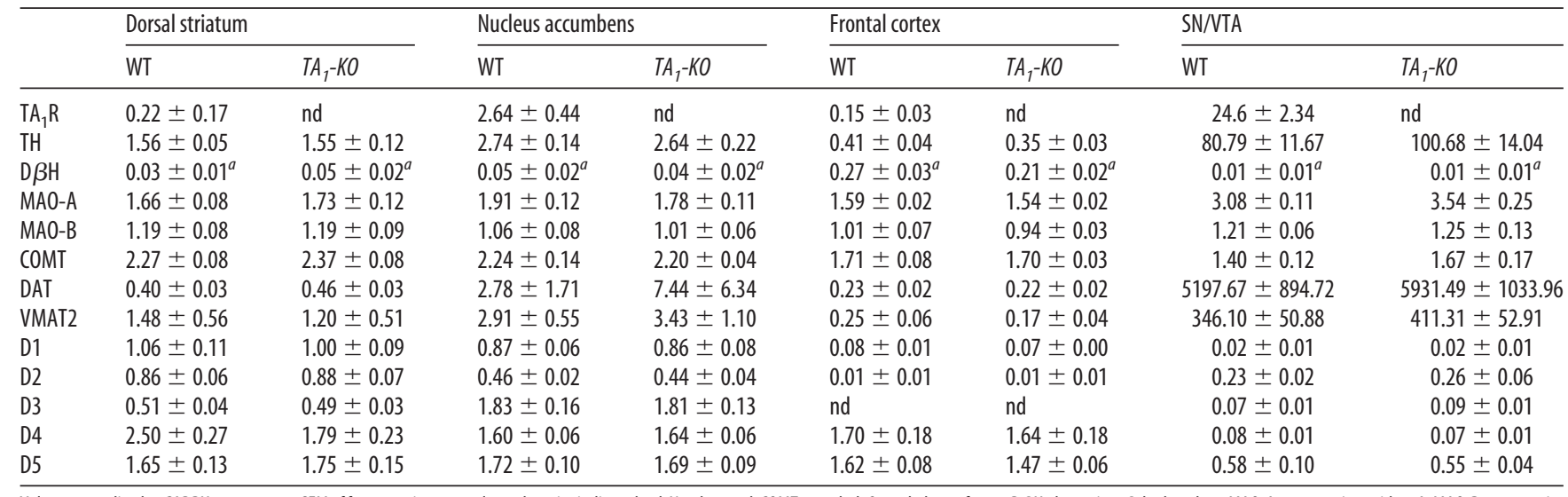

Values, normalized to GADPH, are mean \pm SEM of four experiments, unless otherwise indicated. nd, Not detected; COMT, catechol- 0 -methyl transferase; D $\beta H$, dopamine- $\beta$-hydroxylase; MAO-A, monoamine oxidase A; MAO-B, monoamine oxidase B; SN/VTA, substantia nigra/ventral tegmental area; VMAT-2, vesicular monoamine transporter 2.

${ }^{a}$ Values given as the mean \pm SD of two experiments.

taining Taarl locus have been isolated. The genomic organization of targeted locus was determined by subcloning XbaI ( $6 \mathrm{~kb})$ and SpeI ( $5 \mathrm{~kb})$ genomic fragments into the pZEro-2 vector (Invitrogen). The XbaI and SpeI genomic inserts were sequenced and used to construct the targeting vector. Briefly, a $4.4 \mathrm{~kb}$ XbaI-NsiI fragment comprising Taarl exons 1 (4334 bp 5'UTR +120 bp of coding region) and a $1.1 \mathrm{~kb}$ EcoRI-BglII fragment located downstream of Taarl exon 1 (122 bases of CDS +1046 bp 3' UTR), were used to flank an IRES LacZ-NEO-tk cassette (IRES LacZ-LoxP site-PGK promoter-NEO-tk fusion cDNA-LoxP) (Fig. 1A). The insertion of an IRES-LacZ sequence into the coding region of Taar1 allowed the expression of a truncated $\mathrm{TA}_{1}$ protein of 40 aa instead of 332 aa for the entire protein. The insertion of the selection cassette at $3^{\prime}$ of the EcoRI-BglII fragment left $122 \mathrm{bp}$ of the $3^{\prime}$ Taarl coding sequence. A negative diphtheria toxin selection cassette was introduced at the $5^{\prime}$ of the short arm of homology.

Screening of Taar1-targeted ES cell clones. SmaI-linearized targeting vector was transfected by electroporation into $129 \mathrm{SvPas}$ ES cells $\left(10^{8} \mathrm{ES}\right.$ cells in the presence of $100 \mu \mathrm{g}$ of linearized plasmid, $260 \mathrm{~V}, 500 \mu \mathrm{F}$ ). Positive selection was achieved $48 \mathrm{~h}$ later by addition of $200 \mu \mathrm{g} / \mathrm{ml} \mathrm{G} 418$ $(150 \mu \mathrm{g} / \mathrm{ml}$ active component, Life Technologies). Ninety-nine resistant clones were isolated and amplified in 96-well plates (duplicates). The set of plates containing ES cell clones amplified on gelatin were screened by PCR and further confirmed by Southern blot. The 3' PCR screening conditions were as follows: GW224 primer specific for the Neo-Tk selection cassette (5'-GGCTGCTAAAGCGCATGCTCCAGAC-3'); and GW475 primer that hybridizes the Taarl gene ( $5^{\prime}$-CCGCGGACAGTT TTATGGTGTAACCCTGCCTGACCTG- $3^{\prime}$ ). PCR conditions are $94^{\circ} \mathrm{C} / 5$ min; 35 cycles of $94^{\circ} \mathrm{C} / 30 \mathrm{~s}$ and $68^{\circ} \mathrm{C} / 2 \mathrm{~min} 30 \mathrm{~s}$; and then $68^{\circ} \mathrm{C} / 7 \mathrm{~min}$, which resulted in a $1505 \mathrm{bp}$ band for the mutated allele. PCR reactions were performed using Long Expand High Fidelity polymerase (Roche) and reaction buffer 3 . The $5^{\prime}$ PCR screening conditions were as follows: GW114 primer specific for the IRES-LacZ cassette (5'-CAGTCACGAC GTTGTAAAACGAC-3'), and GW587 primer specific for the Taarl gene (5'-GGAGTCCATCATGCTAAGGTGTCAGG-3'). PCR conditions were $94^{\circ} \mathrm{C} / 5 \mathrm{~min} ; 35$ cycles of $92^{\circ} \mathrm{C} / 30 \mathrm{~s}$ and $58^{\circ} \mathrm{C} / 30 \mathrm{~s}$; and then $68^{\circ} \mathrm{C} / 7 \mathrm{~min}$, which resulted in a $5374 \mathrm{bp}$ band for the mutated allele. For Southern blot analysis, genomic DNA was digested with XbaI and then hybridized with a $0.8 \mathrm{~kb}$ internal probe; Taar ${ }^{+/-}$clones gave rise to a $5.4 \mathrm{~kb}$ wild-type signal and a $10.5 \mathrm{~kb}$ targeted signal. Two clones (1A2 and 1D2) were identified both by PCR and Southern blot as targeting the Taar1 locus (Fig. $1 B-D$ ).

Generation of germ line chimera mice and homozygous breeding. Two floxed mutated Taar 1 ES cell clones (namely, 1A2 and 1D2) were microinjected into C57BL/6 blastocysts. They gave rise to male chimeras with a significant ES cell contribution (Agouti coat color). After mating with C57BL/6 females, germ line transmission was confirmed by the genotyping of tail DNA offspring (PCR and Southern blot analyses). Floxed heterozygous F1 animals were discriminated from wild type by PCR

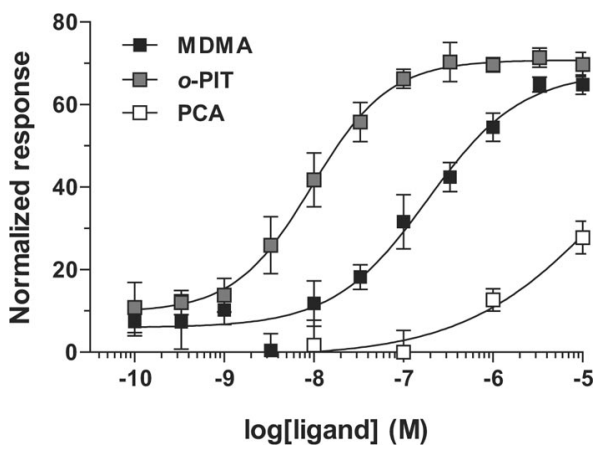

Figure 2. Effect of MDMA, o-PIT, and PCA on CAMP accumulation in a cell line expressing hTA 1 R. cAMP accumulation was assessed by the $\alpha$ screen method $\left(5.10^{4}\right.$ cells/well) in HeLa cells transiently transfected with human $\mathrm{TA}_{1} \mathrm{Rs}$. Data are expressed as a percentage, with $100 \%$ being the inhibition elicited by $1 \mu \mathrm{M}$ CAMP and $0 \%$ being the value with no CAMP (blank). All data are means \pm SEM. $N=3$ per concentration.

using couples primers specific for targeted (GW224/GW475) and wildtype alleles (GW264, 5'-CGACTGGTCAAGAGAAGTCC-3'/GW265, $5^{\prime}$-AGGAGAACCATCTTCAAGGC-3') and by Southern blot on XbaIdigested genomic DNA using an XbaI/HindIII probe specific for the $5^{\prime}$-targeted region (Fig. $1 F, G$ ). Thirty-two heterozygous F1 mice for mutation were generated. Mating of the six heterozygous F1 mice yielded the generation of eight heterozygous and eight homozygous F2 mice for the mutation. Heterozygous and homozygous animals were screened by Southern blot analysis as described above.

Animal. Homozygous $T A_{1}-K O$ mice were backcrossed on pure C57BL/6J genetic background (WT) for eight generations (Charles River). In all experiments, 5-8-week-old male mice were used. They were housed four to five per cage under a $12 \mathrm{~h}$ light/dark cycle and had free access to food and water. Housing (four to five per cage) and experimental procedures ( $12 \mathrm{~h}$ light/dark cycle) were fully compliant with the principles of the Care and Use of Laboratory Animals (European Economic Community directive/86/609).

$q R T-P C R$. Brains were dissected and frozen at $-80^{\circ} \mathrm{C}$, and cerebral structures were removed using a $1.8 \mathrm{~mm}$ diameter punch. Poly A+ RNA was extracted using the MagnaPure LC Isolation station and the MagnaPure LC mRNA Isolation Kit I (Roche Molecular Biochemicals). The RNA samples were subjected to a reverse transcription step using the high-capacity cDNA archive Kit (Applied Biosystems). Single-stranded cDNA products were then analyzed by PCR using the ABI PRISM 7900 HT Sequence Detection System (Applied Biosystems). References of the assays (Applied Biosystems) were as follows: Mm00447557_m1 [tyrosine hydroxylase (TH)]; Mm00460472_m1 (D $\beta \mathrm{H}) ;$ Mm00558009_g1 (MAO-A); Mm00555412_m1 (MAO-B); Mm00514377_ml (COMT); 
A
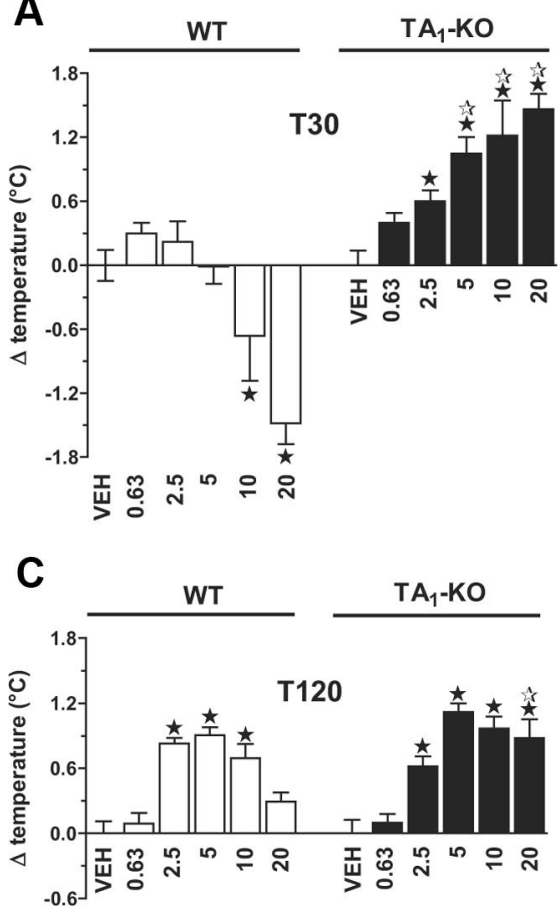

B

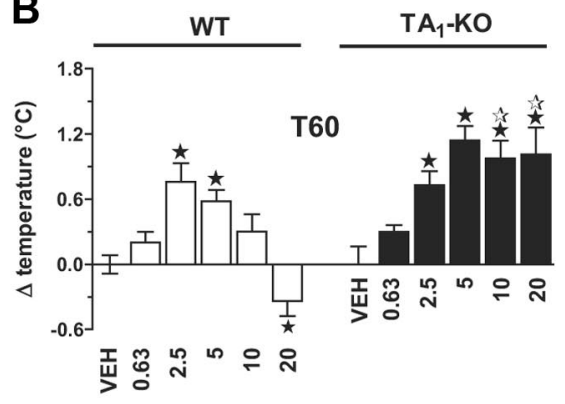

D

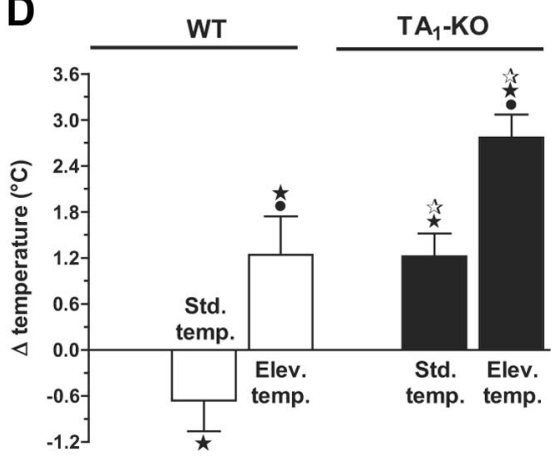

Figure 3. Thermoregulatory response of MDMA in $T A_{1}-K 0$ mice. Body temperature was assessed at T30, T60, and T120 after injection of MDMA $(0.63-20 \mathrm{mg} / \mathrm{kg}$, i.p.), and its effect was expressed as the change from vehicle values. $A-C$, Effect of MDMA on body temperature of WT and $T A_{1}-K O$ mice, under standard condition (ambient temperature of $21^{\circ} \mathrm{C}$ ). $n=6-10 ; p<0.05$,

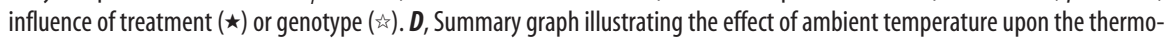
regulatory response of MDMA $(10 \mathrm{mg} / \mathrm{kg})$ at $30 \mathrm{~min}$ postinjection. Body temperature was measured under conditions of elevated temperature $\left(27^{\circ} \mathrm{C}\right.$; Elev. temp.) and "standard" conditions $\left(21^{\circ} \mathrm{C}\right.$; Std. temp.). For simplification of the graph, body temperature changes induced by vehicle are not illustrated (Std. temp.: $0.01 \pm 0.14$ and $-0.34 \pm 0.13$ in WT and $T A_{1}-K 0$, respectively; Elev. temp.: $0.25 \pm 0.19$ and $-0.31 \pm 0.45$ in WT and $T A_{1}-K 0$, respectively). $n=5-11 ; p<0.05$, influence of treatment $(\star)$,

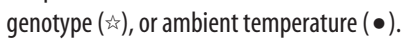

Table 2. Resting dialysate levels of monoamines in freely moving mice

\begin{tabular}{lcc}
\hline & WT (рм) & $T A_{1}-$ KO (рм) \\
\hline Dorsal striatum & & \\
$\quad$ Dopamine & $3000.8 \pm 211.7$ & $2962.7 \pm 169.1$ \\
$\quad$ Serotonin & $99.6 \pm 6.8$ & $88.4 \pm 8.0$ \\
$\quad$ Noradrenaline & bdl & bdl \\
Frontal cortex & & \\
$\quad$ Dopamine & $238.9 \pm 30.1$ & $203.5 \pm 23.8$ \\
$\quad$ Serotonin & $188.3 \pm 15.2$ & $209.1 \pm 22.4$ \\
$\quad$ Noradrenaline & $445.5 \pm 25.8$ & $411.9 \pm 22.5$ \\
Nucleus accumbens & & \\
$\quad$ Dopamine & $385.1 \pm 68.8$ & $396.4 \pm 73.5$ \\
$\quad$ Serotonin & $63.8 \pm 7.5$ & $62.1 \pm 6.1$ \\
$\quad$ Noradrenaline & $151.8 \pm 16.3$ & $132.6 \pm 21.1$ \\
\hline
\end{tabular}

Values are expressed as mean \pm SEM and are not corrected for probe recovery. $N \geq 8$ per group. bdl, Below detection limit.

Mm00553058_m1 (VMAT2); Mm01353211_m1 (D $) ;$ Mm00438541_m1

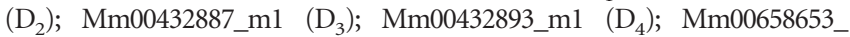
s1 ( $\left.\mathrm{D}_{5}\right)$; and Mm99999915_g1 (GADPH). The TA $\mathrm{R}_{1}$ assay (Applied Biosystems) was a Custom TaqMan Gene Expression assay (Forward primer TTGAGCGCTGTTGGTATTTTGG, Reverse primer GAGGCGGAGCTCAGCAT, Taqman probe CACCAGCACCGATATC). Triplicate threshold cycle $(C t)$ values were averaged and relative gene expression was analyzed using the $\Delta C t$ method (Livak and Schmittgen, 2001) with $\mathrm{GADPH}$ as an endogenous control/reference assay.

Histoenzymology. Brains were dissected, frozen at $-25^{\circ} \mathrm{C} /-30^{\circ} \mathrm{C}$, and embedded in O.C.T. Compound (Tissue-Tek). Sagittal brain sections (30 $\mu \mathrm{m}$ ) were placed on superfrost-plus glass slides (LABOnord) at $-20^{\circ} \mathrm{C}$. Staining was made with the $\beta$-Galactosidase Reporter Gene Staining Kit
(GALS; Sigma-Aldrich) according to the manufacturer's instructions. Counterstained (Nuclear Fast Red, 5 min) and dehydrated sections were then mounted with hydrophobic media then digitalized with NanoZoomer (Hamamatsu).

Cell culture and cAMP accumulation. HeLa cells were incubated at $37^{\circ} \mathrm{C}\left(95 \% \mathrm{O}_{2} / 5 \% \mathrm{CO}_{2}\right)$ in DMEM with fetal bovine serum $5 \%$, penicillin $100 \mathrm{Us} / \mathrm{ml}$, and streptomycin $100 \mu \mathrm{g} / \mathrm{ml}$. Cells were transiently transfected with the 3HA_B2_hTARR1 receptor (Barak et al., 2008) and adenylyl cyclase $\mathrm{V}$ plasmids $(2 \mu \mathrm{g}$ each) using the lipofectamine method. Two days later, HeLa cells were plated into 96-well (5.10 ${ }^{4}$ cells/well) with partially serum-free medium (0.5\% FBS) for $24 \mathrm{~h}$. Accumulation of cAMP was determined using the Alphascreen cAMP detection kit (PerkinElmer). Cells were incubated with MDMA, $o$-PIT, or PCA for $15 \mathrm{~min}$ at $37^{\circ} \mathrm{C}$. The buffer was then removed, and the reaction terminated by lysing and freezing the cells $\left(-70^{\circ} \mathrm{C}\right)$. Samples were transferred to a 384-well white Optiplate (PerkinElmer) and anti-cAMP acceptor beads, then donor beads with biotinylated cAMP were added. Plates were incubated then read using a Fusion- $\alpha$ microplate reader (PerkinElmer). Experiments were run in triplicate. Data were calculated against a standard curve of cAMP concentrations using Origin Pro 7.5 software (OriginLab).

TH phosphorylation in brain slices. Striatal slices (300 $\mu \mathrm{m}$; Vibratome, Leica) were preincubated in Krebs buffer ( $118 \mathrm{~mm} \mathrm{NaCl}, 4.7 \mathrm{~mm}$ $\mathrm{KCl}, 1.5 \mathrm{~mm} \mathrm{Mg}_{2} \mathrm{SO}_{4}, 1.2 \mathrm{~mm} \mathrm{KH}_{2} \mathrm{PO}_{4}, 25 \mathrm{~mm}$ $\mathrm{NaHCO}_{3}, 11.7 \mathrm{~mm}$ glucose, $1.3 \mathrm{~mm} \mathrm{CaCl}$ ) at $30^{\circ} \mathrm{C}$ under constant oxygenation $\left(95 \% \mathrm{O}_{2} / 5 \%\right.$ $\mathrm{CO}_{2}$ ) for $60 \mathrm{~min}$, with a change of buffer after $30 \mathrm{~min}$. They were then treated with MDMA for $5 \mathrm{~min}$. The buffer was then removed, and the slices were rapidly frozen on dry ice, sonicated in $1 \%$ SDS, and boiled for $10 \mathrm{~min}$. The amount of protein in homogenates was determined using the bicinchoninic acid protein assay method (Pierce). Equal amounts of protein were processed by using $10 \%$ acrylamide gels. Immunoblotting was performed with phosphorylation state-specific antibodies against p-Ser19-TH (1:500; AB5425, Millipore), p-Ser31-TH (1:500; AB5423, Millipore, and $p$-Ser40-TH (1:500; AB5935; Millipore), or antibodies that are not phosphorylation state specific against total TH (1:1000; AB152, Millipore) and actin (1:1000; A3853; Sigma). All antibodies stained bands of correct size. The peptide sequences and procedures to generate the antibodies toward TH have been published previously (Haycock et al., 1998; Lew et al., 1999). The site- and phosphorylation state-specific antibodies show selective reactivity of the phospho versus nonphospho forms of TH (Haycock et al., 1998; Lew et al., 1999). Antibody binding was detected by enhanced chemiluminescence (GE Healthcare) and quantified by densitometry (NIH IMAGE 1.61 software).

Core temperature. Experiments were performed in a randomized sequence between 10.00 and 12.00:00 A.M. under standard conditions (ambient temperature $21^{\circ} \mathrm{C}$ ). Core temperature was determined by a procedure adapted for mice and using a rectal thermoprobe (Millan et al., 1994). Core temperature was measured under basal conditions before treatment and 30,60, and 120 min after vehicle or MDMA administration. Under conditions of high ambient temperature, mice were exposed to a temperature of $27^{\circ} \mathrm{C}$ during the $4 \mathrm{~h}$ before the basal core temperature measurement.

Microdialysis in freely moving mice. Mice were anesthetized with pentobarbital $(6 \mathrm{mg} / \mathrm{kg}$, i.p. $)$ before the guide cannula implantation in the dorsal striatum, frontal cortex, or nucleus accumbens. The stereotaxic 
coordinates were as follows (in millimeters from bregma): dorsal striatum: anteroposterior $(\mathrm{AP})+1.0$, lateral $(\mathrm{L}) \pm 1.9$, dorsoventral (DV) -2.2 ; frontal cortex: AP $-2.2, \mathrm{~L} \pm 0.3$, DV -1.0 ; and nucleus accumbens: AP $-1.3, \mathrm{~L}$ \pm 0.6 , DV -4.5 . One week later, a 2.0 or 1.0 $\mathrm{mm}$ (nucleus accumbens) length $\mathrm{CMA} / 7$ probe was inserted and perfused at $1.0 \mu \mathrm{l} / \mathrm{min}$ with PBS ( $\mathrm{NaCl} 147 \mathrm{~mm}, \mathrm{KCl} 4 \mathrm{~mm}, \mathrm{CaCl}_{2} 2.3$ $\mathrm{mM}, \mathrm{pH} 7.2$ ). After a $150 \mathrm{~min}$ elimination period, 20 min samples were collected at $4^{\circ} \mathrm{C}$ on $20 \mu \mathrm{l}$ of ascorbic acid $60 \mu \mathrm{M}$, for $240 \mathrm{~min}$. They were stored at $-80^{\circ} \mathrm{C}$ pending injection $(35$ $\mu l)$. The mobile phase was composed of sodium dihydrogen citrate $25 \mathrm{~mm}$, sodium decanesulfonate $1.8 \mathrm{~mm}$, and methanol $24 \%$ (v/ v), $\mathrm{pH} 5.7$, and delivered at $0.3 \mathrm{ml} / \mathrm{min}$. NA, DA, and 5-HT were separated on a BETASIL C18 column (Thermo Fisher Scientific; $150 \times$ $2.1 \mathrm{~mm}, 3 \mu \mathrm{m})$ at $40^{\circ} \mathrm{C}$. A coulometric detector (Coulochem III, ESA) with analytical cell settled at $\mathrm{E} 1=-70 \mathrm{mV}$ and $\mathrm{E} 2=+300 \mathrm{mV}$ (ESA5041, ESA) was used. The limit of sensitivity was $0.2 \mathrm{pg}$. Dialysis contents of exogenous MDMA were determined using mass spectrometry (Applied Biosystems). The detection limit was $0.2 \mathrm{ng} / \mathrm{ml}$. Area under the curve (AUC) values were calculated using the standard trapezoidal method and expressed as arbitrary units (percentage $\times$ minutes $\times 10^{-3}$ ).

Synaptosomal preparation. Dorsal striata were dissected at $4^{\circ} \mathrm{C}$, and synaptosomal pellet (P2) fractions prepared by suspending the pellet in glucose $0.32 \mathrm{M}(8 \mathrm{mg}$ of protein $/ \mathrm{ml})$. Fractions were diluted (1:10) with Krebs-Ringer medium (130 mm NaCl, $3 \mathrm{~mm} \mathrm{KCl,} 1.2 \mathrm{~mm}$ $\mathrm{MgSO}_{4}, 2.5 \mathrm{~mm} \mathrm{Na}_{2} \mathrm{HPO}_{4}, 1 \mathrm{~mm}$ ascorbic acid, and $20 \mathrm{~mm}$ Tris buffer, $\mathrm{pH} 7.5$ ) and preincubated for $10 \mathrm{~min}$ at $37^{\circ} \mathrm{C}$ in a Dubnoff water bath. Synaptosomes were labeled with $0.1 \mu \mathrm{M}$ $\left[{ }^{3} \mathrm{H}\right] \mathrm{DA}$ or $\left[{ }^{3} \mathrm{H}\right] 5-\mathrm{HT}$ (specific activity 36 and $30 \mathrm{Ci} / \mathrm{mmol}$, respectively; PerkinElmer) for 10 $\min$ at $37^{\circ} \mathrm{C}$. Suspensions were diluted $(1: 10)$ with Krebs-Ringer medium (basal medium, glucose $10 \mathrm{~mm}, \mathrm{pH} 7.5$ ). Aliquots were placed on Millipore filters lying at the bottom of parallel superfusion chambers $\left(37^{\circ} \mathrm{C}\right)$. Under a moderate vacuum, basal medium was used to wash synaptosomes $(10 \mathrm{ml})$, which were then superfused at $0.45 \mathrm{ml} / \mathrm{min}$. After $20 \mathrm{~min}$, synaptosomes were superfused with basal medium alone or a medium containing PCA and/or $o$-PIT. One-minute fractions were collected on $100 \mu \mathrm{l}$ of a protective solution (ascorbic acid 1\%, EDTA $1.5 \%$, and unlabeled neurotransmitter $0.001 \%)$. $\left[{ }^{3} \mathrm{H}\right] \mathrm{DA}$ and $\left[{ }^{3} \mathrm{H}\right] 5-\mathrm{HT}$ in fractions versus synaptosomes were separated from $\left[{ }^{3} \mathrm{H}\right]$ metabolites on Biorex-70 columns and counted using a Packard liquid-scintillation $\beta$-counter. Experiments were run in quadruplicate. Values are percentage of total $\left[{ }^{3} \mathrm{H}\right] \mathrm{DA}$ or $\left[{ }^{3} \mathrm{H}\right] 5$-HT recovered.

Locomotor activity. Testing started at 09:00 A.M. and lasted $180 \mathrm{~min}$. The test cage was made of Plexiglas $(27 \times 20 \times 20 \mathrm{~cm})$ and was illuminated by a $6 \mathrm{~W}$ light. Two opposite sets of six photocells were located $6 \mathrm{~cm}$ apart, $2 \mathrm{~cm}$ above the floor (Hesperid). Every beam interruption corresponded to a locomotion count.

Statistical analysis. Statistical comparisons of the effect of MDMA in WT versus $T A_{1}-K O$ mice were performed using two-way ANOVA with genotype (gen) and drug (drug) between factors and followed by Tukey's post hoc test. The following three-way ANOVAs were used: plus time (time) for within-factor and repeated measurement in kinetic studies of the effect of MDMA; plus pretreatment (pret) for between-factors analysis in drug interaction studies; and plus ambient temperature (amb) for treatment $(\star)$ or genotype ( $\left(\boldsymbol{i}^{2}\right)$.

\section{Dorsal striatum}

\section{B}

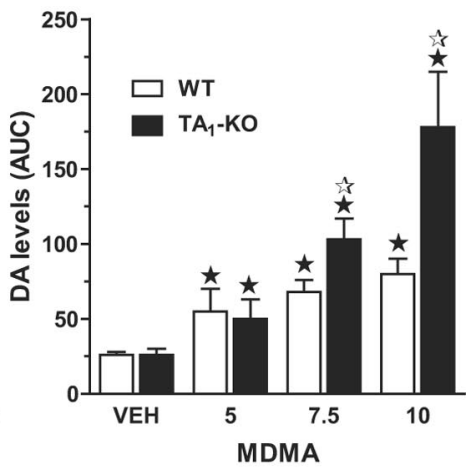

Accumbens

D

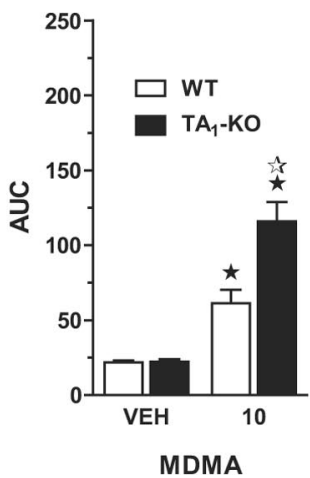

MDMA

Minute

Figure 4. Effect of MDMA on extracellular levels of $D A$ in the dorsal striatum of freely moving $T A_{7}-K O$ mice. $A$, Time course of the 列 C, data were analyzed using repeated measurements over the 180 min postinjection period. $n=5-7, p<0.05$, influence of

between-factors analysis in studies for the effect of ambient temperature on thermoregulation. A value of $p<0.05$ was considered significant.

Drugs. $S(+)-3-4$-methylenedioxymetamphetamine, DL-para-chloroamphetamine, and haloperidol were provided by Sigma. $o$-Phenyl-3iodotyramine hydrochloride and ketanserin were synthesized by Servier chemists. Compounds were dissolved in sterile water plus lactic acid when necessary, then the $\mathrm{pH}$ was adjusted to near neutrality. Drugs were injected in a volume of $10 \mathrm{ml} / \mathrm{kg}$, and doses are expressed in terms of free base. All drugs, with the exception of ketanserin (administered subcutaneously), were administered intraperitoneally. In neurochemical and behavioral studies, a full dose range of MDMA was tested (0.63-20.0 mg/ $\mathrm{kg}$ ), corresponding to doses shown to exert robust and specific actions in previous studies of this agent (Green et al., 2003; Colado et al., 2004), and the actions of MDMA were tested over a range of times (20-180 min).

\section{Results}

Targeting strategy and generation of the $T A_{1}-K O$ mouse line A line of homozygous mice lacking $\mathrm{TA}_{1}$ receptors $\left(T A_{1}-K O\right)$ was generated in which the coding sequence of Taar 1 was replaced by the $L a c Z$ reporter gene, resulting in the production of a radically truncated (42 vs 322 aa) and inactive $\mathrm{TA}_{1} \mathrm{R}$ in vivo (Fig. $1 \mathrm{~A}$ ). PCR of the targeted and $\mathrm{WT} \mathrm{TA}_{1} \mathrm{R}$ gene locus was used to diagnose homologous recombination in embryonic stem cells and in homozygous mutants (Fig. $1 B$ ). The mouse line was generated using targeted derived ES cells and was maintained on a pure 
A

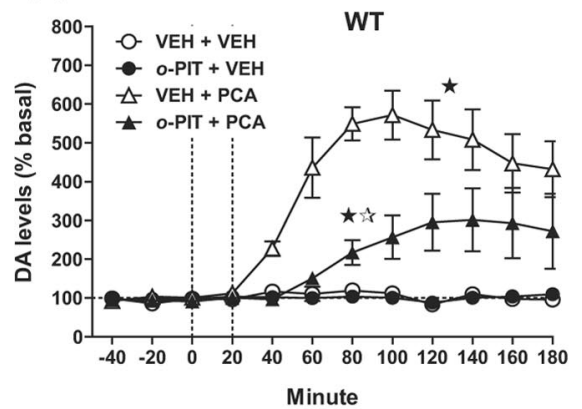

\section{B}
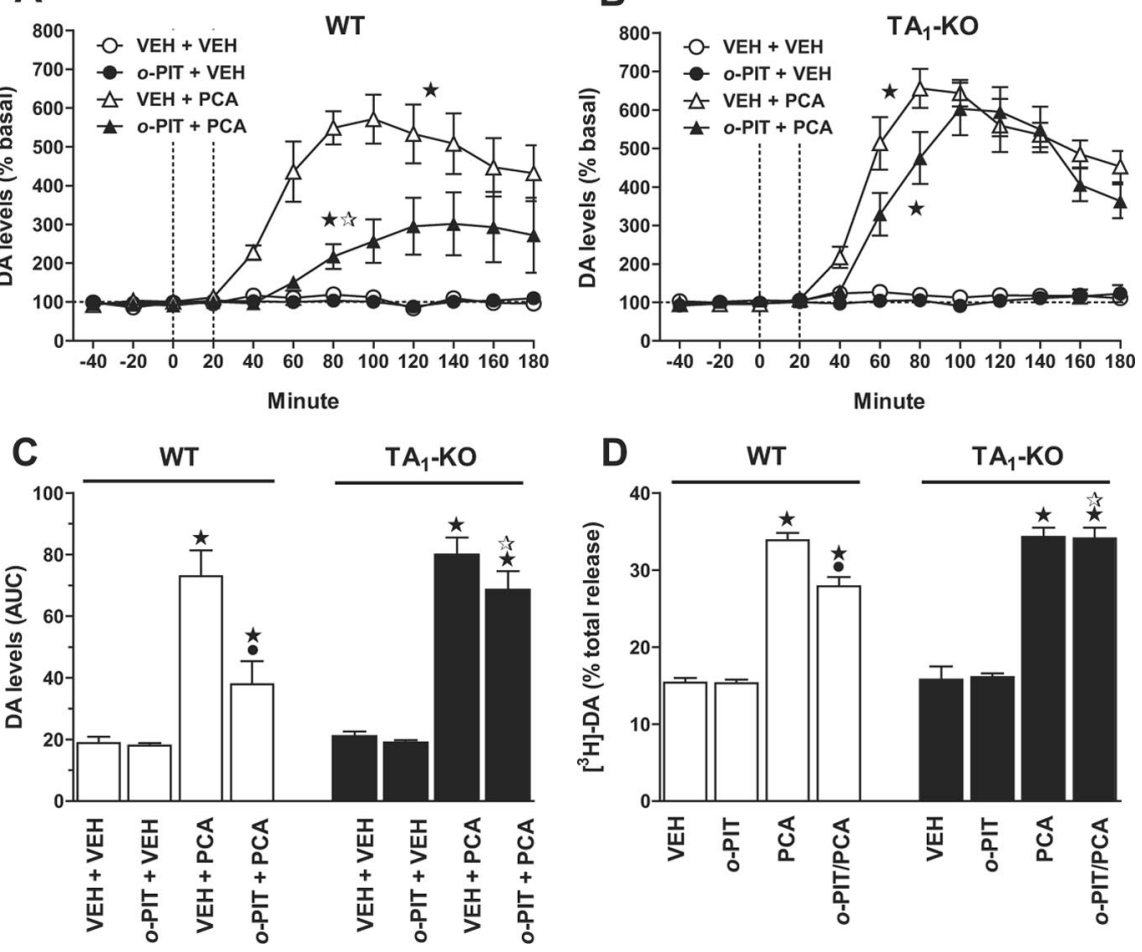

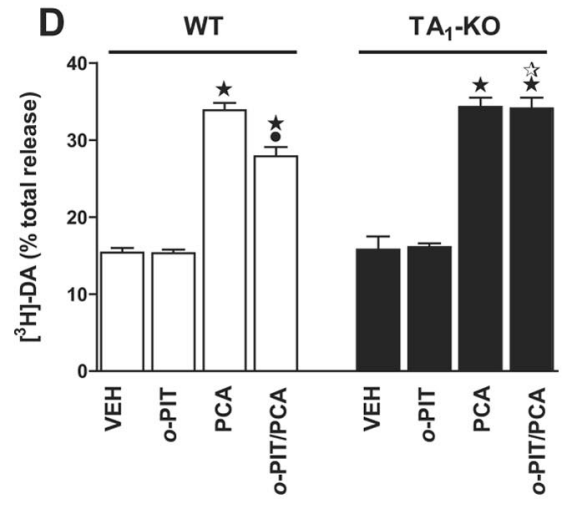

Figure 5. Influence of the TA $A_{1}$ Ragonist 0 -PIT upon the $P C A$-induced release of $D A$ in the dorsal striatum in vivo $(\boldsymbol{A}-\boldsymbol{C})$ and in vitro (D). In freely moving WT mice, but not $T A_{7}-K O$ mice, 0 -PIT significantly reduced the action of PCA. $A, B$, Time course of the effect of o-PIT in combination with PCA upon dialysate levels of DA in the dorsal striatum. o-PIT (10 mg/kg, i.p.) was administered $20 \mathrm{~min}$ before PCA (5 mg/kg, i.p.) (vertical dotted lines) in WT and $T A_{7}-K O$ mice. Changes in DA levels were expressed compared with basal values (100\%). C, Summary graph showing the action of 0 -PIT in combination with PCA, using AUC (percentage $X$ minute $X$ $10^{-3}$; arbitrary units) of observations from 20 to $180 \mathrm{~min}$. D, Histogram of the 0 -PIT/PCA interaction upon the $\left[{ }^{3} \mathrm{H}\right]$-DA release in synaptosomal preparation from dorsal striatum and nucleus accumbens. Perfusion of 0 -PIT (100 nM) significantly reduced the PCA (1 $\mu \mathrm{m}$ )-induced release of [ $\left.{ }^{3} \mathrm{H}\right]$-DA (expressed as a percentage of total [ $\left.{ }^{3} \mathrm{H}\right]$-DA overflow over 6 min of perfusion) in WT but not in

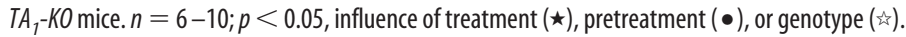

C57BL/6J genetic background (WT mice). In $T A_{1}-\mathrm{KO}$ mice, qRTPCR analysis revealed an absence of mRNA coding $\mathrm{TA}_{1} \mathrm{R}$ in structures known to be enriched in $\mathrm{TA}_{1}$ Rs (Table 1) (Wolinsky et al., 2007; Lindemann et al., 2008). By contrast, in WT mice, higher levels of mRNA coding $\mathrm{TA}_{1} \mathrm{R}$ were detected in the substantia nigra/ventral tegmental area, and in nucleus accumbens, striatum, and frontal cortex (Table 1). Conversely, in $T A_{1}-K O$ mice, these and other regions known to express $\mathrm{TA}_{1} \mathrm{Rs}$ revealed an expression of $\beta$-galactosidase (product of the LacZ reporter gene), as observed by histoenzymology (Fig. $1 \mathrm{H}$ ). Mice were healthy, and ate and grew normally (body weights as adults were $21.6 \pm 0.1$ and $21.4 \pm 0.2 \mathrm{~g}$, respectively, in WT and $T A_{1}-K O$ mice). They showed no gross perturbation of behavior and displayed no difference in basal motor activity (see Fig. 7).

\section{Agonist actions of MDMA at recombinant \\ HeLa-expressed hTA $R$}

Since trace amine family receptors are notoriously difficult to functionally express in cell systems (Lindemann and Hoener, 2005; Grandy, 2007), we designed a TA $\mathrm{R}$ bearing an asparaginelinked glycosylation site at its $\mathrm{N}$ terminus to facilitate plasma membrane expression and pharmacological characterization: in addition, we boosted coupling sensitivity by cotransfecting adenylyl cyclase $\mathrm{V}$, which may also act as a chaperone to promote $\mathrm{TA}_{1} \mathrm{R}$ cell surface expression (Dupré et al., 2007). Using this system, MDMA was found to concentration-dependently stimulate the production of cAMP with an efficacy similar to that of $o$-PIT
(Scanlan et al., 2004; Hart et al., 2006). However, MDMA was less potent than $o$-PIT, as indicated by a significant difference in $\mathrm{EC}_{50}$ values $\left(F_{(1,4)}=29.2, p<\right.$ $0.01)$, which were $167.5 \pm 38.8 \mathrm{nM}$ for MDMA and $9.5 \pm 0.6 \mathrm{nM}$ for $o$-PIT. In contrast to MDMA, PCA only weakly stimulated CAMP production even at very high concentrations up to $10 \mu \mathrm{M}$ (Fig. 2).

\section{Influence of MDMA upon core temperature in $T A_{1}-K O$ mice}

Under standard conditions of $21^{\circ} \mathrm{C}$ ambient temperature, basal core temperature did not differ between WT and $T A_{1}-K O$ mice $\left(38.1 \pm 0.1^{\circ} \mathrm{C}\right.$ in each case; $F_{(1,73)}=$ 0.9 , NS). Administration of MDMA to WT mice induced a dose-dependent (0.63-20 mg/kg, i.p.) and biphasic thermoregulatory response with a rapidly occurring hypothermia (30 min postinjection; T30) (Fig. 3A) followed by a gradual hyperthermia from 60 (T60) to 120 min (T120) (Fig. $3 B, C$ ). In contrast, $T A_{1}-K O$ mice displayed only a longlasting hyperthermia. The maximal genotype difference was detected at T30, with $-1.5 \pm 0.2^{\circ} \mathrm{C}$ and $+1.5 \pm 0.1^{\circ} \mathrm{C}$, respectively, in WT and $\mathrm{TA}_{1}-\mathrm{KO}$ mice. ANOVA revealed a significant gen $X$ drug interaction $\left(F_{(5,63)}=16.6, p<0.01\right)$. Differences in genotype were also detected at T60 and T120, at which time point a more pronounced hyperthermia was measured in $T A_{1}-K O$ mice (gen $\times$ drug interactions: $F_{(5,63)}=6.0, p<0.01$ and $F_{(5,63)}=2.3$, $p<0.05$ at T60 and T120, respectively).

Increasing ambient temperature to $27^{\circ} \mathrm{C}$ (elevated temperature) did not reveal genotype difference in basal core temperature (gen $\times$ amb interaction: $F_{(1,48)}=0.7$, NS), which was significantly lower compared with standard condition $\left(F_{(1,50)}=57.3\right.$, $p<0.01): 37.2 \pm 0.1^{\circ} \mathrm{C}$ and $37.3 \pm 0.2^{\circ} \mathrm{C}$, respectively, in WT and $T A_{1}-K O$ mice. The effect of genotype upon the MDMA response at T30 $(10 \mathrm{mg} / \mathrm{kg})$ (Fig. 3D) was found to not be influenced by ambient temperature (gen $\times$ drug $\times$ amb interaction: $F_{(1,44)}=$ 0.2 , NS). The effects of MDMA under increased ambient temperature were magnified compared with standard temperature (drug $\times$ amb interaction: $\left.F_{(1,48)}=10.2, p<0.01\right)$ and were still significantly different between $T A_{1}-K O\left(+2.8 \pm 0.3^{\circ} \mathrm{C}\right)$ and $\mathrm{WT}\left(+1.2 \pm 0.5^{\circ} \mathrm{C}\right)$ mice $\left(\right.$ gen $\times$ drug interaction: $F_{(1,48)}=$ $10.9, p<0.01)$.

The effect of the $5-\mathrm{HT}_{2 \mathrm{~A}}$ antagonist ketanserin $(0.63 \mathrm{mg} / \mathrm{kg}$, s.c.) on the hyperthermia elicited by MDMA (20 mg/kg, i.p.) was evaluated under standard conditions at $90 \mathrm{~min}$ after injection (data not shown). Ketanserin significantly reduced MDMAinduced hyperthermia (pret $\times$ drug interaction: $F_{(1,58)}=5.1, p<$ $0.05)$, and its action was similar in both genotypes as indicated by a nonsignificant gen $\times$ pret $\times$ drug interaction $\left(F_{(1,58)}=3.7\right.$, NS), lowering the MDMA-induced hyperthermia from $+0.5 \pm$ $0.1^{\circ} \mathrm{C}$ to $-0.7 \pm 0.4^{\circ} \mathrm{C}$ and from $+1.3 \pm 0.1^{\circ} \mathrm{C}$ to $+0.5 \pm 0.1^{\circ} \mathrm{C}$, respectively, in $\mathrm{WT}$ and $T A_{1}-\mathrm{KO}$ mice. Ketanserin, by itself, slightly decreased core temperature $\left(-0.2 \pm 0.2^{\circ} \mathrm{C}\right.$ in WT mice; $-0.6 \pm 0.2^{\circ} \mathrm{C}$ in $T A_{1}-K O$ mice) when compared with vehicle 
$\left(0.0 \pm 0.1^{\circ} \mathrm{C}\right.$ change in both cases). By contrast with ketanserin, core temperature was unaffected by antagonists at $\mathrm{D}_{1}$, $\mathrm{D}_{2}, \alpha_{2}$, and $5-\mathrm{HT}_{1 \mathrm{~A}}$ sites SCH23390, raclopride, RX821002, and WAY100635, respectively (data not shown).

\section{Dialysis levels of exogenous MDMA in the dorsal striatum of} $T A_{1}-K O$ mice

A dedicated set of microdialysis experiments was performed to verify the exposure to MDMA in the dorsal striatum of WT and $T A_{1}-K O$ mice. To this end, dialysate levels of (exogenous) MDMA were determined by mass spectrometry following its intraperitoneal administration $(10 \mathrm{mg} / \mathrm{kg})$. Exposure to MDMA was similar as determined by both (1) AUC $(165 \pm 19$ in WT mice and $183 \pm 33$ in $T A_{1}-K O$ mice) and (2) maximal concentrations $(2085 \pm 378 \mathrm{ng} / \mathrm{ml}$ in WT mice and $1997 \pm 252 \mathrm{ng} / \mathrm{ml}$ $T A_{1}-K O$ mice). No statistical difference was observed throughout the 180 min of observation, and ANOVA indicated a nonsignificant gen $\times$ time interaction $\left(F_{(8,72)}=0.5, \mathrm{NS}\right)$. Hence, differences in the functional response to MDMA between $T A_{1}-K O$ and WT mice cannot be attributed to an alteration in its penetration of the blood-brain barrier and differential accumulation of MDMA in the brain.

\section{Effect of MDMA on dialysis levels of DA in the dorsal} striatum and nucleus accumbens of $T A_{1}-K O$ mice

Under basal conditions, extracellular levels of DA in dorsal striatum and nucleus accumbens of freely moving mice did not significantly differ between WT and $T A_{1}-K O$ mice (Table 2).

In the dorsal striatum, MDMA ( $10 \mathrm{mg} / \mathrm{kg}$, i.p.) elicited a sustained and robust increase in DA levels (Fig. $4 A$ ). Its maximal magnitude was significantly higher in $T A_{1}-K O$ mice compared with WT mice (1756 \pm 361 and $909 \pm 133 \%$ of baseline, respectively) and was revealed by a significant gen $\times$ drug $\times$ time interaction $\left(F_{(11,198)}=7.8, p<0.01\right)$. The overall influence of genotype upon the effect of MDMA was dependent upon the dose of MDMA (5-10 mg/kg) (Fig. 4B), as indicated by a significant gen $\times$ drug interaction $\left(F_{(3,38)}=5.0, p<0.01\right)$.

In the nucleus accumbens, MDMA (10 mg/kg) (Fig. $4 C)$ also provoked a pronounced increase in DA levels, which reached a higher maximal value in $T A_{1}-K O$ mice than in WT mice (1316 \pm 145 and $630 \pm 73 \%$ of baseline). The hypersensitivity of $T A_{1}-K O$ mice was revealed by a significant gen $\times$ drug $\times$ time interaction $\left(F_{(11,220)}=16.8, p<0.01\right)$. The overall effect of MDMA was also significant with a gen $\times$ drug interaction $\left(F_{(1,20)}=13.0, p<0.01\right)$ (Fig. 4C).

\section{Influence of $o$-PIT upon PCA-induced release of DA in the dorsal striatum of $T A_{1}-K O$ mice}

Administration of PCA ( $5 \mathrm{mg} / \mathrm{kg}$, i.p.) elevated DA levels in the dorsal striatum with a similar magnitude in WT and $T A_{1}-K O$ mice (571 \pm 63 and $655 \pm 50 \%$, respectively). Pretreatment with the TA 1 agonist, $o$-PIT $(10 \mathrm{mg} / \mathrm{kg}$, i.p.), which did not affect DA levels by itself, significantly blunted the action of PCA in WT mice, lowering its maximal effect to $301 \pm 81 \%$ (Fig. $5 \mathrm{~A}$ ) and was, however, inactive in $T A_{1}-K O$ mice (Fig. $5 B$ ). ANOVA indicated a significant pret $\times$ drug $\times$ time interaction in WT mice $\left(F_{(11,187)}=\right.$ $3.6, p<0.01)$ but not $T A_{1}-K O\left(F_{(11,176)}=2.1, \mathrm{NS}\right)$ mice. The influence of the genotype was revealed by the analysis of the AUC values and the significant gen $\times$ pret $\times$ drug interaction $\left(F_{(1,34)}=\right.$ $6.1, p<0.05)$ (Fig. $5 C$ ).

The influence of $o$-PIT upon PCA-induced $\left[{ }^{3} \mathrm{H}\right]$-DA overflow was also evaluated in striatal and accumbal synaptosomes from $T A_{1}-K O$ mice. Basal release of $\left[{ }^{3} \mathrm{H}\right]-\mathrm{DA}$ was not influenced by
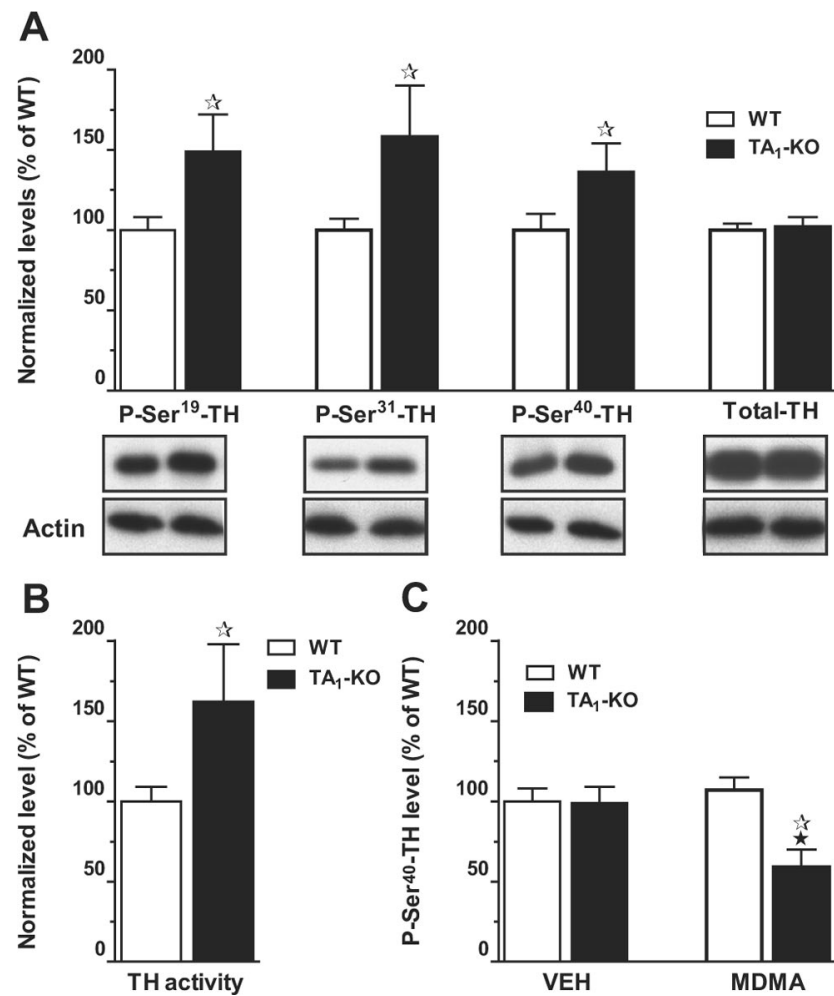

Figure 6. Phosphorylation state and activity of $\mathrm{TH}$ in slices from the dorsal striatum of $T A_{1}$-KO mice. $A$, Levels of $p$-Ser19-TH, $p$-Ser31-TH, and $p$-Ser40-TH, adjusted to actin, compared with WT value (100\%) and illustrated by representative immunoblots (inserts), were increased in $T A_{7}-K O$ mice. Levels of total TH were unchanged in $T A_{7}-K O$ mice. $\boldsymbol{B}$, Measurement of the enzymatic activity of TH in the dorsal striatum of $T A_{1}-K O$ mice. Compared with WT value (100\%), TH activity was significantly increased in $T A_{1}-K O$ mice. $C$, Influence of MDMA on levels of $p$-Ser40-TH in the dorsal striatum. The perfusion of MDMA $(100 \mathrm{nM})$ significantly reduced the levels of $p$-Ser40-TH (\% of WT value) in TA, $-K O$ mice but not in WT mice. $n=4-5 ; p<0.05$, influence of treatment $(\star)$ or genotype $($ 衫).

genotype and was $15.4 \pm 0.6$ and $15.8 \pm 1.7 \%$ of total release, respectively, in WT and $T A_{1}-K O$ mice. Perfusion of $o$-PIT (100 nM) did not affect the basal release of [ $\left.{ }^{3} \mathrm{H}\right]-\mathrm{DA}$ (Fig. 5D), whereas PCA $(1 \mu \mathrm{M})$ significantly increased $\left[{ }^{3} \mathrm{H}\right]$-DA overflow in preparation from WT and $T A_{1}-K O$ mice $(33.9 \pm 0.9$ and $34.3 \pm 1.2 \%$, respectively). In WT mice, the effect of PCA upon $\left[{ }^{3} \mathrm{H}\right]-\mathrm{DA}$ was significantly reduced by coperfusion of $o$-PIT (gen $\times$ drug interaction: $F_{(1,6)}=18.1, p<0.01$ ), lowering its overflow to $27.9 \pm 1.2 \%$ of total release. In contrast, $o$-PIT was inactive in preparations from $T A_{1}-K O$ mice $(34.1 \pm 1.4 \%)$.

\section{Levels of $p$-Ser-TH and TH activity in dorsal striatum of} $T A_{1}-K O$ mice, and influence of MDMA upon $p$-Ser40-TH The basal phosphorylation state of TH at Ser19, Ser31, and Ser40 residues was significantly $(p<0.05)$ increased in striatal slices from $T A_{1}-K O$ mice when compared with WT mice (Fig. $6 A$ ). No corresponding difference was found in total levels of $\mathrm{TH}$, which correlates with the absence of significant difference in the expression of mRNA coding TH (Table 1). Basal TH activity, measured by DOPA accumulation in striatal slices, was significantly higher in $T A_{1}-K O$ mice when compared with WT mice $(p<0.05)$ (Fig. $6 B)$. In response to MDMA, levels of $p$-Ser40-TH were decreased in $T A_{1}-K O$ mice, but not in WT mice (Fig. $6 C$ ). ANOVA indicated a significant gen $\times$ drug interaction $\left(F_{(1,32)}=6.6, p<0.05\right)$.

By analogy to $\mathrm{TH}$, as depicted in Table 1 , there were no significant differences between WT and $T A_{1}-K O$ mice as regards the 

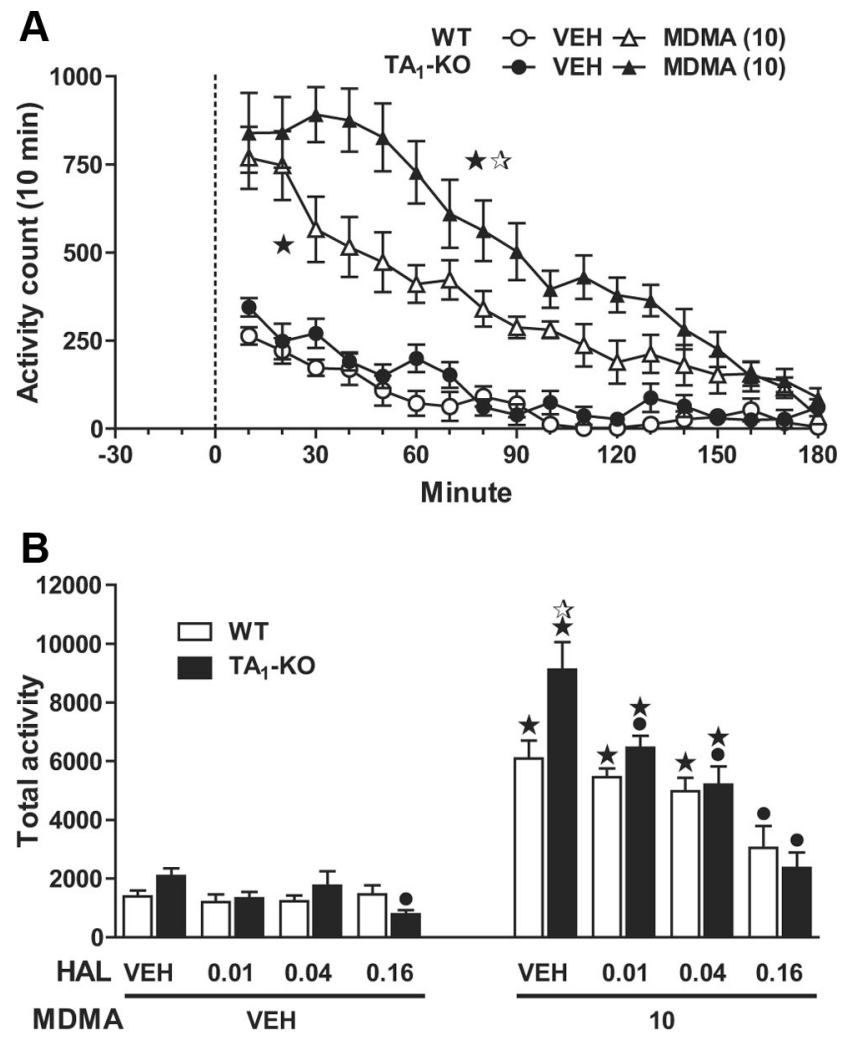

Figure 7. Influence of MDMA on locomotor activity in $T A_{1}-K O$ mice. $A$, Time course of the action of MDMA over a $180 \mathrm{~min}$ period. The effect of MDMA $(10 \mathrm{mg} / \mathrm{kg}$, i.p.; vertical dotted line) on locomotor activity was measured by $10 \mathrm{~min}$ bin in WT and $T A_{1}-K O$ mice. $\boldsymbol{B}$, Histogram showing the abrogation of the action of MDMA $(10 \mathrm{mg} / \mathrm{kg})$ by the dopamine $D_{2}$ antagonist haloperidol. The increase in locomotor activity (total count over the 180 $\mathrm{min}$ ) was dose-dependently reduced by haloperidol $(0.01-0.16 \mathrm{mg} / \mathrm{kg}$, i.p.), administered 30 min later. $n=6-12 ; p<0.05$, influence of treatment $(\star)$, pretreatment $(\bullet)$, or genotype (初).

levels of mRNA encoding various substrates controlling the activity of dopaminergic pathways, including catabolic enzymes, DA transporters, and both $\mathrm{D}_{2} / \mathrm{D}_{3}$ autoreceptors. Hence, putative changes in these mechanisms cannot account for alterations in the influence of MDMA upon extracellular levels of DA in $T A_{1}-K O$ versus WT mice.

\section{Influence of MDMA in interaction with haloperidol upon locomotor activity in $\mathrm{TA}_{1}-\mathrm{KO}$ mice}

Spontaneous locomotor activity was not significantly different between WT and TA $-K O$ mice $(392 \pm 20$ and $406 \pm 19$ counts, respectively). MDMA (10 $\mathrm{mg} / \mathrm{kg}$, i.p.) increased locomotion more robustly in $T A_{1}-K O$ than WT mice (gen $\times$ drug $\times$ time interaction: $\left.F_{(20,520)}=2.2, p<0.01\right)$ (Fig. $7 A$ ). The locomotoractivating action of MDMA was blocked by haloperidol (Fig. $7 B$ ). This interaction was not influenced by genotype (gen $\times$ pret $X$ drug interaction: $\left.F_{(3,98)}=1.4, \mathrm{NS}\right)$. In both genotypes, the effect of MDMA was dose-dependently prevented by haloperidol (0.01-0.16 mg/kg, i.p.; pret $\times$ drug interaction: $F_{(3,49)}=5.1, p<$ 0.01 and $F_{(3,49)}=9.1, p<0.01$, respectively, in WT and $T A_{1}-K O$ mice), and was totally abolished by $0.16 \mathrm{mg} / \mathrm{kg}$ haloperidol. Furthermore, haloperidol was more potent in reducing the effect of MDMA in $T A_{1}-K O$ than in WT mice (minimal effective doses were 0.01 and $0.16 \mathrm{mg} / \mathrm{kg}$, respectively).
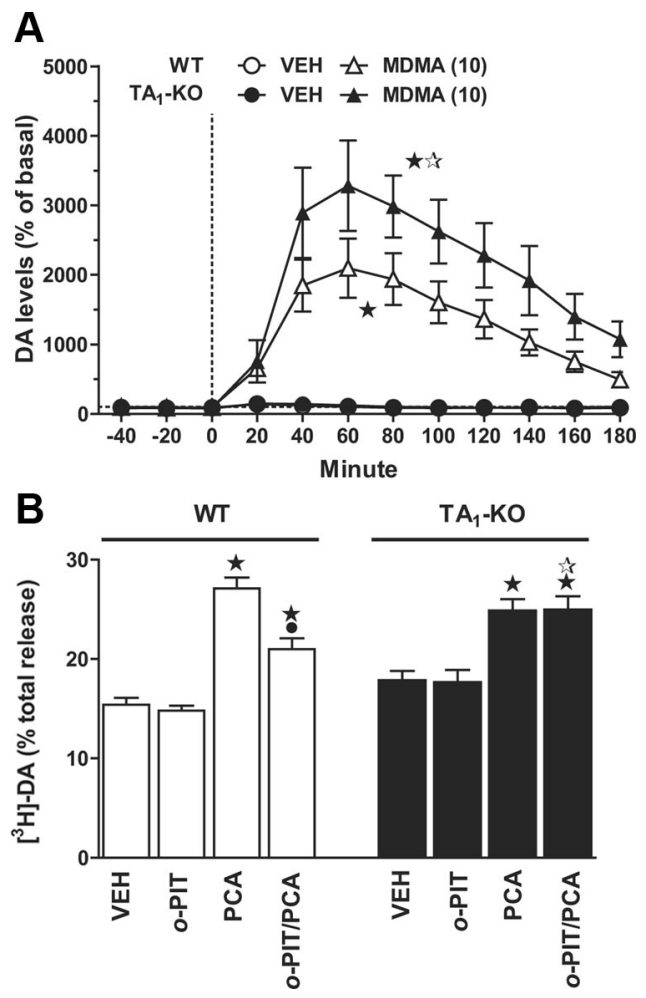

Figure 8. Effect of MDMA on extracellular levels of DA in the frontal cortex, in vivo $(\boldsymbol{A})$ and influence of 0 -PIT upon the PCA-induced released of DA in the frontal cortex, in vitro $(\boldsymbol{B})$. $\boldsymbol{A}$, Administration of MDMA ( $10 \mathrm{mg} / \mathrm{kg}$, i.p.; vertical dotted line) elevated DA dialysate levels from basal levels (expressed as $100 \%$ ). The action of MDMA was more pronounced in $T A_{1}-K 0$ than in WT mice. AUC (percentage $\times$ minute $\times 10^{-3}$; arbitrary units) values are as follows: vehicle, $17.9 \pm 1.4$ and MDMA, $231.6 \pm 40.8$, in WT mice; vehicle, $19.5 \pm 1.3$ and MDMA, $374.2 \pm$ 74.7, in $T A_{1}-K O$ mice. $B$, Histogram showing the 0 -PIT/PCA interaction on $\left[{ }^{3} \mathrm{H}\right]$-DA release in synaptosomal preparation from frontal cortex. Perfusion of 0 -PIT $(100 \mathrm{~nm})$ significantly reduced the PCA (1 $\mu \mathrm{m}$ )-induced release of $\left[{ }^{3} \mathrm{H}\right]$-DA (expressed as percentage of total [ $\left.{ }^{3} \mathrm{H}\right]$-DA overflow over 6 min of perfusion) in WT but not in $T A_{1}-K O$ mice. $n=6-10 ; p<0.05$, influence of treatment $(\star)$, pretreatment $(\bullet)$, or genotype (汶).

\section{Effect of MDMA upon DA transmission in the frontal cortex of $T A_{1}-K O$ mice}

Basal extracellular levels of DA in the frontal cortex of $T A_{1}-K O$ mice were not significantly different from WT mice (Table 2). In the frontal cortex, MDMA (10 mg/kg, i.p.) increased levels of DA (Fig. $8 A$ ), an effect that was amplified in $T A_{1}-K O$ compared with WT mice ( $3280 \pm 650$ and $2096 \pm 425 \%$ of baseline, respectively; gen $\times$ drug $\times$ time interaction: $\left.F_{(11,209)}=3.4, p<0.05\right)$.

In synaptosomal preparations from frontal cortex, basal release of cortical $\left[{ }^{3} \mathrm{H}\right]$-DA was not statistically influenced by genotype and was $15.4 \pm 0.7$ and $17.8 \pm 1.0 \%$ of total release, respectively, in WT and $T A_{1}-K O$ mice. The release of $\left[{ }^{3} \mathrm{H}\right]-\mathrm{DA}$ was not altered by the perfusion of $o$-PIT $(100 \mathrm{nM})$, but was significantly increased by PCA $(1 \mu \mathrm{M})$ in WT and $T A_{1}-K O$ mice $(27.1 \pm 1.1$ and $24.8 \pm 1.2 \%$ of total release, respectively) (Fig. $8 B$ ). Coperfusion of $o$-PIT with PCA significantly reduced the effect of PCA to $21.0 \pm 1.1 \%$ of total release in synaptosomes from WT mice (gen $\times$ drug interaction: $\left.F_{(1,8)}=5.8, p<0.05\right)$ but not $T A_{1}-K O$ mice $(24.9 \pm 1.4 \%)$.

\section{Effect of MDMA on 5-HT transmission in $T A_{1}-K O$ mice}

Extracellular levels of 5-HT in the dorsal striatum, nucleus accumbens, or frontal cortex of freely moving mice did not significantly differ between WT and $T A_{1}-\mathrm{KO}$ mice (Table 2). 
In the dorsal striatum, MDMA (10 mg/ $\mathrm{kg}$, i.p.) elicited a sustained and robust increase in 5-HT levels (Fig. 9A). Its maximal magnitude was significantly higher in $T A_{1}-K O$ mice compared with WT mice $(2139 \pm 175$ and $938 \pm 174 \%$ of baseline, respectively), as revealed by a significant gen $\times$ drug $\times$ time interaction $\left(F_{(11,198)}=12.2, p<0.01\right)$. The overall influence of genotype upon the effect of MDMA was dependent upon the dose of MDMA (5-10 mg/kg) (Fig. 9B), as indicated by a significant gen $X$ drug interaction $\left(F_{(3,37)}=10.9, p<0.01\right)$.

In the nucleus accumbens, MDMA (10 $\mathrm{mg} / \mathrm{kg}$ ) (Fig. 9C) increased 5-HT levels to a greater extent in $T A_{1}-K O$ than in WT mice $(2937 \pm 389$ and $1931 \pm 163 \%$ of baseline). ANOVA indicated a significant gen $\times$ drug $\times$ time interaction $\left(F_{(11,220)}=\right.$ $4.2, p<0.01)$.

In frontal cortex, MDMA (10 mg/kg) increased levels of 5-HT (Fig. 9D), an effect that was not significantly influenced by genotype $(2074 \pm 130$ and $1797 \pm$ $355 \%$ of baseline, respectively, in WT and $T A_{1}-K O$ mice; $\left.F_{(11,220)}=0.2, \mathrm{NS}\right)$.

Influence of $o$-PIT upon PCA-induced release of 5-HT in the dorsal striatum of $T A_{1}-K O$ mice

Administration of PCA ( $5 \mathrm{mg} / \mathrm{kg}$, i.p.) elevated 5-HT levels in the dorsal striatum with a comparable magnitude in WT and $T A_{1}-K O$ mice $(1180 \pm 105$ and $1250 \pm$ $111 \%$, respectively). Pretreatment with the TA 1 agonist $o$-PIT (10 mg/kg, i.p.), which did not affect 5-HT levels by itself, significantly blunted the action of PCA in WT mice-lowering its maximal effect to $663 \pm 100 \%$ (Fig. 10A)but not in $T A_{1}-K O$ mice (Fig. $10 B$ ). ANOVA indicated a significant pret $\times$ drug $\times$ time interaction in $\mathrm{WT}$ mice $\left(F_{(11,187)}=11.9\right.$, $p<0.01)$, but not in $T A_{1}-K O$ mice $\left(F_{(11,176)}=2.0\right.$, NS). The influence of the genotype was revealed by analysis of the AUC values and the significant gen $\times$ pret $\times$ drug interaction $\left(F_{(1,34)}=\right.$ 3.4, $p<0.05$ ) (Fig. 10C).

In synaptosomal preparation from dorsal striatum, basal release of $\left[{ }^{3} \mathrm{H}\right]-5-\mathrm{HT}$ was not influenced by genotype and was $7.0 \pm 0.6$ and $8.7 \pm 0.8 \%$ of total release, respectively, in WT and $T A_{1}-K O$ mice. Perfusion of $o$-PIT $(100 \mathrm{nM})$ did not affect the release of $\left[{ }^{3} \mathrm{H}\right]-5-\mathrm{HT}$ (Fig. $\left.10 \mathrm{D}\right)$, whereas PCA (1 $\left.\mu \mathrm{M}\right)$ significantly increased $\left[{ }^{3} \mathrm{H}\right]-5-\mathrm{HT}$ overflow in preparations from WT and $T A_{1}-K O$ mice $(27.2 \pm 1.3 \%$ and $27.7 \pm 2.2 \%$, respectively). In WT mice, the effect of PCA upon $\left[{ }^{3} \mathrm{H}\right] 5-\mathrm{HT}$ was significantly reduced by coperfusion of $o$-PIT (gen $\times$ drug interaction: $F_{(1,6)}=$ $6.8, p<0.05)$, lowering its overflow to $22.6 \pm 1.2 \%$ of total release. In contrast, $o$-PIT was inactive in $T A_{1}-K O$ mice $(26.9 \pm$ $1.4 \%)$.

\section{Discussion}

Agonist properties of MDMA at $\mathrm{hTA}_{1} \mathrm{R}$

The prototypical agonist, $o$-PIT (Scanlan et al., 2004; Barak et al., 2008) stimulated $\mathrm{TA}_{1}$ Rs, and less potent but equi-effective activation of $\mathrm{TA}_{1} \mathrm{R}$ was seen with MDMA. Like $o$-PIT, MDMA also

\section{Dorsal striatum}

B

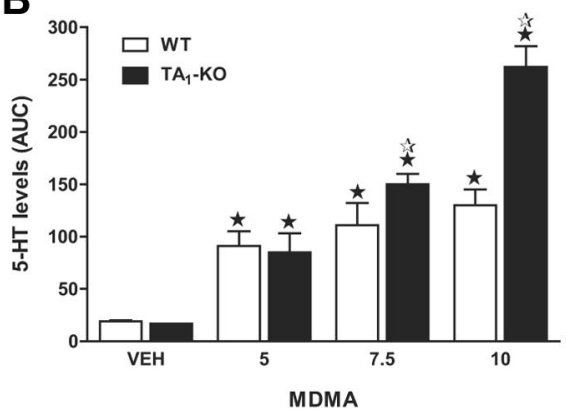

Frontal cortex

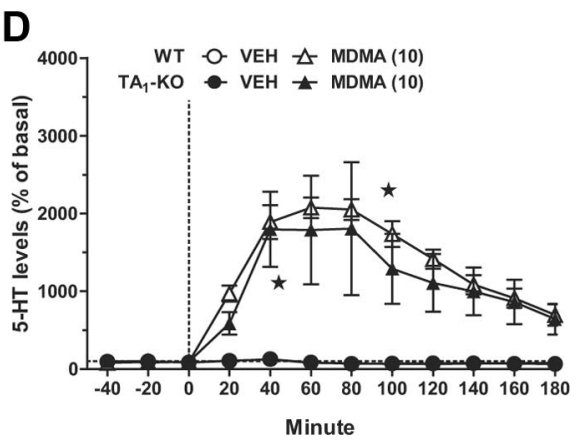

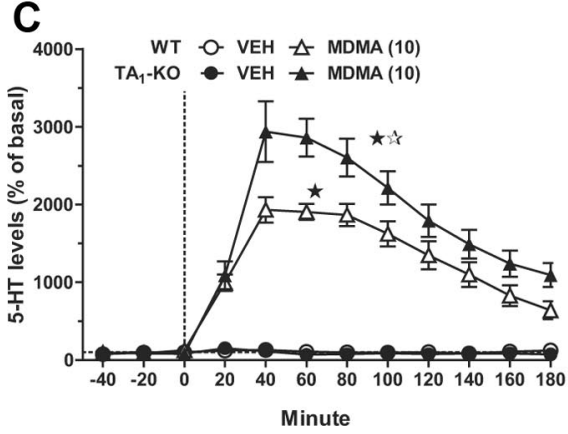

Minute

Figure 9. Action of MDMA on extracellular levels of $5-\mathrm{HT}$ in the dorsal striatum, nucleus accumbens, and frontal cortex of freely moving WT and $T A_{7}-K O$ mice. $A$, Time course of the effect of MDMA on 5 -HT levels in the dorsal striatum. Administration of MDMA $(10 \mathrm{mg} / \mathrm{kg}$, i.p.; vertical dotted line) robustly increased 5 -HT levels. $B$, Dose-response relationship of the effect of MDMA on striatal the frontal cortex. AUC values in WT mice: $15.3 \pm 1.0$, vehicle; and $250.6 \pm 17.6$, MDMA. AUC values in $T A_{1}-K O$ mice: $14.9 \pm 0.7$, vehicle; and $212.1 \pm 67.4$, MDMA. $n=5-8 ; p<0.05$, influence of treatment $(\star)$ or genotype (战).

binds murine $\mathrm{TA}_{1}$ Rs (Bunzow et al., 2001; Hu et al., 2009). In contrast to MDMA, PCA was essentially inactive at hTA $\mathrm{R}$. The interaction of $o$-PIT with TA $\mathrm{R}$ (Scanlan et al., 2004) was specific in that it showed $\sim 100$-fold lower potency (M. J. Millan, unpublished observation) in G-protein coupling studies of sites controlling monoaminergic transmission, core temperature, and locomotor activity: notably, dopamine $\mathrm{D}_{2} / \mathrm{D}_{3}, 5-\mathrm{HT}_{1 \mathrm{~A}}$, and $\alpha_{2 \mathrm{~A}^{-}}$ adrenergic receptors, which act as autoreceptors on dopaminergic, serotonergic, and adrenergic pathways, respectively (Millan et al., 2000a).

\section{Reinforcement of the hyperthermic actions of MDMA in $T A_{1}-K O$ mice}

MDMA exerts a complex influence upon core temperature (Green et al., 2003; Rodsiri et al., 2011) and elicited a biphasic time- and dose-dependent hypothermia-hyperthermia in WT mice, which was transformed into a monophasic, rapid, and dose-dependent hyperthermia in $T A_{1}-K O$ counterparts. Increasing ambient temperature favors hyperthermia (Green et al., 2003; Feduccia et al., 2010) and exaggerated the hyperthermic response to MDMA in $T A_{1}-K O$ mice, consistent with the hypothermic impact of TA ${ }_{1}$ R activation (Scanlan et al., 2004; Hart et al., 2006). These observations amplify the suggestion of Panas et al. (2010) that recruitment of $\mathrm{TA}_{1} \mathrm{R}$ by MDMA restrains its hyperthermic properties. The hypothermia-mediating populations of $\mathrm{TA}_{1} \mathrm{R}$ that modulate the influence of MDMA on core temperature are probably localized in thermoregulatory centers like medial optic area and arcuate hypothalamus (Borowsky et al., 2001; Har- 

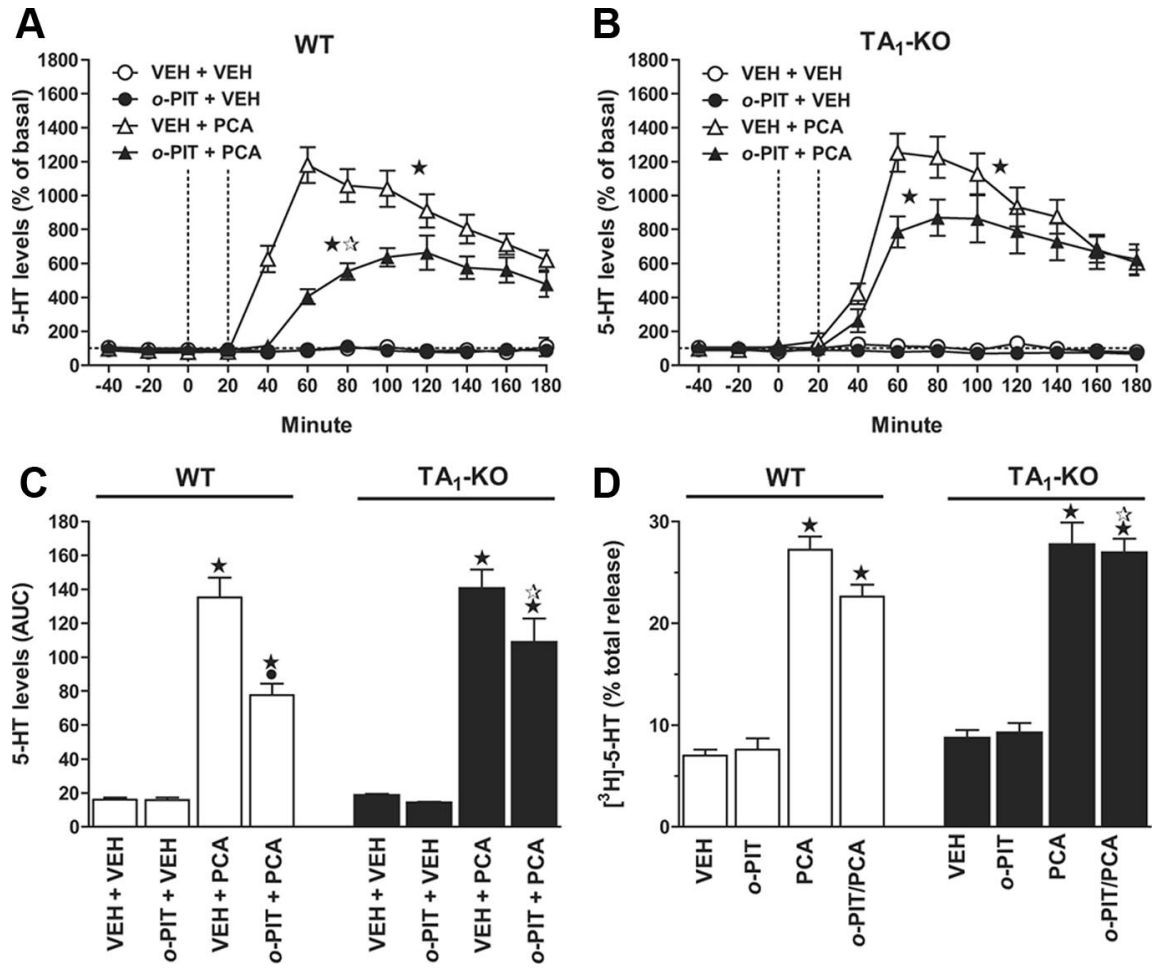

Figure 10. Influence of o-PIT upon the PCA-elicited release of 5-HT in the dorsal striatum in vivo $(A-C)$ and in vitro (D). $A, B$, Time course of the effect of 0 -PIT in combination with PCA upon dialysate levels of $5-\mathrm{HT}$ in the dorsal striatum. o-PIT $(10 \mathrm{mg} / \mathrm{kg}$, i.p.), administered $20 \mathrm{~min}$ before PCA (5 mg/kg, i.p.) (vertical dotted lines), significantly reduced the action of PCA on 5 -HT levels (expressed in percentage from basal) in WT but not in $T A_{7}-K O$ mice. C, Summary graph showing the action of o-PIT in combination with PCA, using AUC (percentage $\times$ minute $\times 10^{-3}$; arbitrary units) of observations from 20 to $180 \mathrm{~min}$. $\boldsymbol{D}$, Histogram of the 0 -PIT/PCA interaction upon the $\left[{ }^{3} \mathrm{H}\right]-5-\mathrm{HT}$ release in synaptosomal preparation from dorsal striatum and nucleus accumbens. Perfusion of 0 -PIT (100 nM) reduced the PCA $\left(1 \mu \mathrm{M}\right.$ )-induced release of [ $\left.{ }^{3} \mathrm{H}\right]-5$-HT (expressed as percentage of total [ $\left.{ }^{3} \mathrm{H}\right]-5$-HT overflow over 6 min perfusion) in WT but not in $T A_{1}-K 0$ mice. $n=4-10 ; p<0.05$, influence of treatment $(\star)$, pretreatment $(\bullet)$, or genotype (觙).

greaves et al., 2007; Bratincsák et al., 2008). Alternatively, they might be situated in monoaminergic neurons themselves (Mechan et al., 2002; Herin et al., 2005; Bexis and Docherty, 2008). Nonetheless, $\mathrm{D}_{2} / \mathrm{D}_{3}, 5-\mathrm{HT}_{1 \mathrm{~A}}$, and $\alpha_{2}$-adrenergic autoreceptors are not involved in MDMA-induced hypothermia since antagonists did not modify its influence on core temperature (see Results) (Fig. 3). Conversely, the 5- $\mathrm{HT}_{2 \mathrm{~A}}$ receptor blocker ketanserin blunted the hyperthermic effects of MDMA both in $T A_{1}-K O$ and WT mice (Liechti et al., 2000; Docherty and Green, 2010), consistent with clinical studies of the hyperthermia provoked by MDMA in humans (Vollenweider et al., 2002; Docherty and Green, 2010).

\section{Amplification of MDMA-induced increases in dialysis levels of DA in $T A_{1}-K O$ mice}

$T A_{1}-K O$ mice are modestly hypersensitive to increases in extracellular levels of DA provoked by amphetamine in dorsal striatum (Wolinsky et al., 2007; Lindemann et al., 2008). The present data expand these studies in demonstrating that genetic deletion of $\mathrm{TA}_{1} \mathrm{R}$ markedly enhances MDMA-induced extracellular DA not only in dorsal striatum but also nucleus accumbens and frontal cortex. This robust potentiation reflects the potent and highefficacy actions of MDMA at $\mathrm{TA}_{1} \mathrm{R}$, compared with the weak partial agonist effects of amphetamine (Borowsky et al., 2001; Barak et al., 2008; Lindemann et al., 2008). The phasic role of $\mathrm{TA}_{1} \mathrm{R}$ in auto-inhibiting actions of MDMA at striatal and frontocortical dopaminergic terminals was further exemplified using
$o$-PIT (Scanlan et al., 2004; Hart et al., 2006), which blunted elevations in dialysis levels of DA elicited by PCA in WT but not $T A_{1}-K O$ mice. This action of $o$-PIT was reproduced in striatal-accumbal and frontocortical synaptosomes, demonstrating that it occurs at dopaminergic terminals. This demonstration that $\mathrm{TA}_{1} \mathrm{R}$ modulate mesolimbic and frontocortical as well as nigrostriatal dopaminergic projections is important in view of their distinctive functional roles (Hauber, 2010). The precise mechanisms involved require additional study, but activation of $\mathrm{TA}_{1} \mathrm{R}$ probably interferes with the operation of dopamine transporters (DATs) and/or $\mathrm{D}_{2} / \mathrm{D}_{3}$ autoreceptors both at the level of perikarya (Table 1; Lindemann et al., 2008; Bradaia et al., 2009; Ledonne et al., 2010) and terminals (Xie and Miller, 2007, 2008; Xie et al., 2008).

\section{Amplification of the influence of MDMA upon locomotor activity}

Mirroring data from dialysis, induction of locomotor activity by MDMA was more pronounced in $T A_{1}-K O$ versus WT mice, and its actions were dose-dependently abrogated by haloperidol (Ball et al., 2003; Jaworski et al., 2003). Similarly, an enhanced locomotor response to amphetamine was seen in mice genetically deprived of $\mathrm{TA}_{1} \mathrm{R}$ (Wolinsky et al., 2007; Lindemann et al., 2008). Future studies should examine MDMA-responsive procedures monitoring reward mechanisms and drug-seeking behavior, such as place preference and self-administration. It would also be interesting to examine the influence of MDMA on prepulse inhibition (PPI) since MDMA disrupts sensorimotor gating in mice and humans (Vollenweider et al., 1999; Braff et al., 2001; Liechti et al., 2000), and PPI is blunted in $T A_{1}-K O$ versus WT mice (Wolinsky et al., 2007).

\section{Alterations in MDMA-induced striatal TH phosphorylation in $T A_{1}-K O$ mice}

TH phosphorylation at Ser19, Ser31, and Ser40, was increased in $T A_{1}-K O$ mice. These sites are regulated by distinct mechanisms: increases in intracellular $\mathrm{Ca}^{2+}$ stimulate phosphorylation of Ser19; extracellular signal-regulated protein kinases promote phosphorylation at Ser31; and phosphorylation of Ser40 is catalyzed by protein kinase A (Haycock, 1993). Since the phosphorylation state of all three sites is increased by stimulation of dopaminergic fibers (Haycock and Haycock, 1991), it is interesting that the firing rate of dopaminergic neurons is accelerated in $T A_{1}-K O$ versus WT littermates (Lindemann et al., 2008), and (in vitro) in WT mice treated with the TA $\mathrm{R}_{1}$ antagonist EPPTB (Bradaia et al., 2009). Correspondingly, increased basal phosphorylation of $\mathrm{TH}$ in $T A_{1}-K O$ mice may reflect elevated activity of dopaminergic neurons. Furthermore, enhanced phosphorylation of TH stimulates enzymatic activity (Haycock and Haycock, 1991), and increased $\mathrm{TH}$ activity was also seen in $T A_{1}-K O$ mice. 
Intriguingly, MDMA did not affect $\mathrm{TH}$ phosphorylation at Ser40 in WT versus $T A_{1}-K O$ mice. DA, acting via inhibitory $\mathrm{D}_{2}$ autoreceptors on dopaminergic terminals, inhibits Ser40-TH phosphorylation (Haycock and Haycock, 1991; Lindgren et al., 2001 ), and an increased proportion of striatal high-affinity $D_{2}$ receptors was seen in $T A_{1}-K O$ versus WT mice (Wolinsky et al., 2007). Likewise, quinpirole more potently stimulated $D_{2}$ receptor-mediated functional responses in $T A_{1}-\mathrm{KO}$ mice (Bradaia et al., 2009). Hence, MDMA-released DA may more potently trigger $\mathrm{D}_{2}$ autoreceptor-mediated inhibition of TH phosphorylation in $T A_{1}-K O$ compared with WT mice. Furthermore, $o$-PIT increases phosphorylation at Ser40-TH independently of dopaminergic transmission (P. Svenningsson, unpublished observations), so loss of this $\mathrm{TA}_{1} \mathrm{R}$-mediated stimulatory influence of MDMA on TH phosphorylation likely contributes to lower TH phosphorylation following MDMA treatment of $T A_{1}-K O$ versus WT mice.

\section{Amplification of MDMA-induced increases in dialysis 5-HT of $T A_{1}-K O$ mice}

Despite localization of $\mathrm{TA}_{1} \mathrm{R}$ in raphe nuclei (Wolinsky et al., 2007), their potential influence on serotonergic pathways remains undocumented. Suggesting a phasic, inhibitory influence of $\mathrm{TA}_{1} \mathrm{R}$ upon serotonergic transmission and the effects of MDMA, its elevation of extracellular 5-HT was magnified in dorsal striatum and nucleus accumbens of $T A_{1}-K O$ mice, whereas the influence of PCA was unaffected. Together with the observation that $o$-PIT reduced PCA-elicited increases in extracellular 5 -HT in WT but not $T A_{1}-K O$ mice, these observations suggest that intrinsic agonist actions of MDMA at $\mathrm{TA}_{1} \mathrm{R}$ blunt its influence upon serotonergic transmission. Moreover, a direct influence of $\mathrm{TA}_{1} \mathrm{R}$ on serotonergic nerve endings is probably involved since $o$-PIT attenuated PCA-elicited increases in superfusate concentrations of 5-HT in synaptosomal preparations derived from WT but not $T A_{1}-K O$ mice. By analogy to interactions between $\mathrm{TA}_{1} \mathrm{R}$ and DATs in dopaminergic neurons (Sotnikova et al., 2008; Xie and Miller, 2007), $\mathrm{TA}_{1}$ Rs may alter extracellular 5-HT levels through functional interactions with serotonin transporters (SERTs): activation of $\mathrm{TA}_{1} \mathrm{R}$ by MDMA may decrease the operation by SERTs via kinase-mediated phosphorylation (Ramamoorthy et al., 2007; Millan et al., 2008). Alternatively, mimicking interactions between $\mathrm{TA}_{1} \mathrm{R}$ and $\mathrm{D}_{2} / \mathrm{D}_{3}$ autoreceptors (see Introduction), $\mathrm{TA}_{1} \mathrm{R}$ may interact with $5-\mathrm{HT}_{1 \mathrm{~B}}$ autoreceptors (Millan et al., 2000b) and/or their protein partner, p11, to inhibit liberation of 5-HT (Svenningsson et al., 2006; Millan et al., 2008).

The frontal cortex and dorsal striatum are predominantly innervated by the raphe nuclei, and PCA-induced elevations in 5-HT levels were blunted by $o$-PIT in frontocortical and striatal synaptosomes of WT but not $T A_{1}-K O$ mice. Surprisingly, then, there was no phenotypic variation as regards the influence of MDMA upon 5-HT levels in dialysates of frontal cortex. Such a regional difference in the impact of MDMA on serotonergic transmission resembles observations with neurokinin1 receptor antagonists (Guiard et al., 2007; Gobert et al., 2009).

\section{MDMA-induced increases in dialysis levels of NA in $T A_{1}-K O$ mice}

Finally, by analogy to striatal levels of amphetamine (Lindemann et al., 2008), MDMA-elicited increases in NA levels were slightly amplified in frontal cortex and nucleus accumbens of $T A_{1}-K O$ mice. In frontal cortex, NA reuptake is controlled by DATs (Millan et al., 2000b), so a mechanism similar to that modulating levels of DA may be involved. As regards nucleus accumbens, NA is primarily derived from adrenergic neurons (Gobert et al., 2004), suggesting that NA overflow may be under the control of $\mathrm{TA}_{1} \mathrm{R}$. However, mRNA encoding $\mathrm{TA}_{1} \mathrm{R}$ has not yet been observed in the locus ceruleus, so these observations await mechanistic clarification.

\section{Pathophysiological relevance and concluding comments}

The present studies reveal that $\mathrm{TA}_{1}$ Rs exert a widespread, phasic, and inhibitory influence upon cerebral monoaminergic transmission expressed not only in dorsal striatum but also in nucleus accumbens and frontal cortex, and not only against DA but also 5-HT and, albeit weakly, NA. In contrast to Gi-coupled monoaminergic autoreceptors (Millan et al., 2000a), $\mathrm{TA}_{1}$ Rs couple positively via $G_{\alpha \mathrm{i}}$ to adenylyl cyclase. Hence, cellular cascades intervening in its influence upon monoamine release likely differ to those engaged by classical G-protein-coupled receptors (Xie and Miller, 2007; Xie et al., 2008).

The present data also demonstrate that MDMA auto-restrains its influence upon extracellular levels of monoamines by recruiting colocalized $\mathrm{TA}_{1} \mathrm{R}$. Since the present work was undertaken in mice with constitutively deleted $\mathrm{TA}_{1} \mathrm{Rs}$, it would be interesting to perform comparable studies of adult-onset and/or regionally specific deletion of $\mathrm{TA}_{1} \mathrm{R}$. In addition, because young adults frequently take multiple doses of MDMA over long periods, it would be interesting to examine the effects of chronic exposure to MDMA in $T A_{1}-K O$ mice.

Finally, from a clinical perspective, the present data raise the possibility that genetic factors, epigenetic programming, and/or environmental modulation of $\mathrm{TA}_{1} \mathrm{R}$ gene expression may modify individual risk upon exposure to MDMA.

\section{References}

Ball KT, Budreau D, Rebec GV (2003) Acute effects of 3,4-methylenedioxymethamphetamine on striatal single-unit activity and behavior in freely moving rats: differential involvement of dopamine $\mathrm{D}(1)$ and $\mathrm{D}(2)$ receptors. Brain Res 994:203-215.

Barak LS, Salahpour A, Zhang X, Masri B, Sotnikova TD, Ramsey AJ, Violin JD, Lefkowitz RJ, Caron MG, Gainetdinov RR (2008) Pharmacological characterization of membrane-expressed human trace amine-associated receptor 1 (TAAR1) by a bioluminescence resonance energy transfer cAMP biosensor. Mol Pharmacol 74:585-594.

Baumann MH, Clark RD, Budzynski AG, Partilla JS, Blough BE, Rothman RB (2005) N-substituted piperazines abused by humans mimic the molecular mechanism of 3,4-methylenedioxymethamphetamine (MDMA, or “ecstasy”). Neuropsychopharmacology 30:550-560.

Baumann MH, Wang X, Rothman RB (2007) 3,4-Methylenedioxymethamphetamine (MDMA) neurotoxicity in rats: a reappraisal of past and present findings. Psychopharmacology (Berl) 189:407-424.

Baumann MH, Clark RD, Rothman RB (2008) Locomotor stimulation produced by 3,4-methylenedioxymethamphetamine (MDMA) is correlated with dialysate levels of serotonin and dopamine in rat brain. Pharmacol Biochem Behav 90:208-217.

Bedi G, Phan KL, Angstadt M, de Wit H (2009) Effects of MDMA on sociability and neural response to social threat and social reward. Psychopharmacology (Berl) 207:73-83.

Berry MD (2004) Mammalian central nervous system trace amines. Pharmacologic amphetamines, physiologic neuromodulators. J Neurochem 90:257-271.

Bexis S, Docherty JR (2008) Role of alpha1-adrenoceptor subtypes in the effects of methylenedioxy methamphetamine (MDMA) on body temperature in the mouse. Br J Pharmacol 153:591-597.

Borowsky B, Adham N, Jones KA, Raddatz R, Artymyshyn R, Ogozalek KL, Durkin MM, Lakhlani PP, Bonini JA, Pathirana S, Boyle N, Pu X, Kouranova E, Lichtblau H, Ochoa FY, Branchek TA, Gerald C (2001) Trace amines: identification of a family of mammalian -coupled receptors. Proc Natl Acad Sci U S A 98:8966-8971.

Bradaia A, Trube G, Stalder H, Norcross RD, Ozmen L, Wettstein JG, Pinard 
A, Buchy D, Gassmann M, Hoener MC, Bettler B (2009) The selective antagonist EPPTB reveals TAAR1-mediated regulatory mechanisms in dopaminergic neurons of the mesolimbic system. Proc Natl Acad Sci U S A 106:20081-20086.

Braff DL, Geyer MA, Swerdlow NR (2001) Human studies of prepulse inhibition of startle: normal subjects, patient groups, and pharmacological studies. Psychopharmacology (Berl) 156:234-258.

Branchek TA, Blackburn TP (2003) Trace amine receptors as targets for novel therapeutics: legend, myth and fact. Curr Opin Pharmacol 3:90-97.

Bratincsák A, Kovács ZI, Palkovits M (2008) Direct neuronal projection from a brainstem thermosensitive cell group to the preoptic thermoregulatory center. Neuroscience 156:966-972.

Bunzow JR, Sonders MS, Arttamangkul S, Harrison LM, Zhang G, Quigley DI, Darland T, Suchland KL, Pasumamula S, Kennedy JL, Olson SB, Magenis RE, Amara SG, Grandy DK (2001) Amphetamine, 3,4methylenedioxymethamphetamine, lysergic acid diethylamide, and metabolites of the catecholamine neurotransmitters are agonists of a rat trace amine receptor. Mol Pharmacol 60:1181-1188.

Burchett SA, Hicks TP (2006) The mysterious trace amines: protean neuromodulators of synaptic transmission in mammalian brain. Prog Neurobiol 79:223-246.

Colado MI, O'Shea E, Green AR (2004) Acute and long-term effects of MDMA on cerebral dopamine biochemistry and function. Psychopharmacology (Berl) 173:249-263.

Docherty JR, Green AR (2010) The role of monoamines in the changes in body temperature induced by 3,4-methylenedioxymethamphetamine (MDMA, ecstasy) and its derivatives. Br J Pharmacol 160:1029-1044.

Doyle KP, Suchland KL, Ciesielski TM, Lessov NS, Grandy DK, Scanlan TS, Stenzel-Poore MP (2007) Novel thyroxine derivatives, thyronamine and 3-iodothyronamine, induce transient hypothermia and marked neuroprotection against stroke injury. Stroke 38:2569-2576.

Dupré DJ, Baragli A, Rebois RV, Ethier N, Hébert TE (2007) Signalling complexes associated with adenylyl cyclase II are assembled during their biosynthesis. Cell Signal 19:481-489.

Feduccia AA, Kongovi N, Duvauchelle CL (2010) Heat increases MDMAenhanced NAcc 5-HT and body temperature, but not MDMA selfadministration. Eur Neuropsychopharmacol 20:884-894.

Geracitano R, Federici M, Prisco S, Bernardi G, Mercuri NB (2004) Inhibitory effects of trace amines on rat midbrain dopaminergic neurons. Neuropharmacology 46:807-814.

Gobert A, Rivet JM, Lejeune F, Newman-Tancredi A, Adhumeau-Auclair A, Nicolas JP, Cistarelli L, Melon C, Millan MJ (2000) Serotonin(2C) receptors tonically suppress the activity of mesocortical dopaminergic and adrenergic, but not serotonergic, pathways: a combined dialysis and electrophysiological analysis in the rat. Synapse 36:205-221.

Gobert A, Billiras R, Cistarelli L, Millan MJ (2004) Quantification and pharmacological characterization of dialysate levels of noradrenaline in the striatum of freely-moving rats: release from adrenergic terminals and modulation by alpha2-autoreceptors. J Neurosci Methods 140:141-152.

Gobert A, Brocco M, Dekeyne A, Di Cara B, Bouchez G, Lejeune F, Gannon RL, Millan MJ (2009) Neurokininl antagonists potentiate antidepressant properties of serotonin reuptake inhibitors, yet blunt their anxiogenic actions: a neurochemical, electrophysiological, and behavioral characterization. Neuropsychopharmacology 34:1039-1056.

Gough B, Imam SZ, Blough B, Slikker W Jr, Ali SF (2002) Comparative effects of substituted amphetamines (PMA, MDMA, and METH) on monoamines in rat caudate: a microdialysis study. Ann N Y Acad Sci 965:410-420.

Grandy DK (2007) Trace amine-associated receptor 1-Family archetype or iconoclast? Pharmacol Ther 116:355-390.

Green AR, Mechan AO, Elliott JM, O'Shea E, Colado MI (2003) The pharmacology and clinical pharmacology of 3,4-methylenedioxymethamphetamine (MDMA, "ecstasy"). Pharmacol Rev 55:463-508.

Guiard BP, Guilloux JP, Reperant C, Hunt SP, Toth M, Gardier AM (2007) Substance P neurokinin 1 receptor activation within the dorsal raphe nucleus controls serotonin release in the mouse frontal cortex. Mol Pharmacol 72:1411-1418.

Hargreaves GA, Hunt GE, Cornish JL, McGregor IS (2007) High ambient temperature increases 3,4-methylenedioxymethamphetamine (MDMA, "ecstasy")-induced Fos expression in a region-specific manner. Neuroscience 145:764-774.

Hart ME, Suchland KL, Miyakawa M, Bunzow JR, Grandy DK, Scanlan TS
(2006) Trace amine-associated receptor agonists: synthesis and evaluation of thyronamines and related analogues. J Med Chem 49:1101-1112.

Hauber W (2010) Dopamine release in the prefrontal cortex and striatum: temporal and behavioural aspects. Pharmacopsychiatry 43 [Suppl 1]:S32-S41.

Haycock JW (1993) Multiple signaling pathways in bovine chromaffin cells regulate tyrosine hydroxylase phosphorylation at Ser19, Ser31, and Ser40. Neurochem Res 18:15-26.

Haycock JW, Haycock DA (1991) Tyrosine hydroxylase in rat brain dopaminergic nerve terminals. Multiple-site phosphorylation in vivo and in synaptosomes. J Biol Chem 266:5650-5657.

Haycock JW, Lew JY, Garcia-Espana A, Lee KY, Harada K, Meller E, Goldstein M (1998) Role of serine-19 phosphorylation in regulating tyrosine hydroxylase studied with site- and phosphospecific antibodies and sitedirected mutagenesis. J Neurochem 71:1670-1675.

Herin DV, Liu S, Ullrich T, Rice KC, Cunningham KA (2005) Role of the serotonin 5-HT2A receptor in the hyperlocomotive and hyperthermic effects of (+)-3,4-methylenedioxymethamphetamine. Psychopharmacology (Berl) 178:505-513.

Hu LA, Zhou T, Ahn J, Wang S, Zhou J, Hu Y, Liu Q (2009) Human and mouse trace amine-associated receptor 1 have distinct pharmacology towards endogenous monoamines and imidazoline receptor ligands. Biochem J 424:39-45.

Iravani MM, Asari D, Patel J, Wieczorek WJ, Kruk ZL (2000) Direct effects of 3,4-methylenedioxymethamphetamine (MDMA) on serotonin or dopamine release and uptake in the caudate putamen, nucleus accumbens, substantia nigra pars reticulata, and the dorsal raphe nucleus slices. Synapse 36:275-285.

Jaworski JN, Kozel MA, Philpot KB, Kuhar MJ (2003) Intra-accumbal injection of CART (cocaine-amphetamine regulated transcript) peptide reduces cocaine-induced locomotor activity. J Pharmacol Exp Ther 307:1038-1044

Johansen PØ, Krebs TS (2009) How could MDMA (ecstasy) help anxiety disorders? A neurobiological rationale. J Psychopharmacol (Oxford) 23:389-391.

Karlsen SN, Spigset O, Slørdal L (2008) The dark side of ecstasy: neuropsychiatric symptoms after exposure to 3,4-methylenedioxymethamphetamine. Basic Clin Pharmacol Toxicol 102:15-24.

Ledonne A, Federici M, Giustizieri M, Pessia M, Imbrici P, Millan MJ, Bernardi G, Mercuri NB (2010) Trace amines depress D(2)-autoreceptormediated responses on midbrain dopaminergic cells. Br J Pharmacol 160:1509-1520

Leonardi ET, Azmitia EC (1994) MDMA (ecstasy) inhibition of MAO type A and type B: comparisons with fenfluramine and fluoxetine (Prozac). Neuropsychopharmacology 10:231-238.

Lew JY, Garcia-Espana A, Lee KY, Carr KD, Goldstein M, Haycock JW, Meller E (1999) Increased site-specific phosphorylation of tyrosine hydroxylase accompanies stimulation of enzymatic activity induced by cessation of dopamine neuronal activity. Mol Pharmacol 55:202-209.

Liberles SD, Buck LB (2006) A second class of chemosensory receptors in the olfactory epithelium. Nature 442:645-650.

Liechti ME, Baumann C, Gamma A, Vollenweider FX (2000) Acute psychological effects of 3,4-methylenedioxymethamphetamine (MDMA, "ecstasy") are attenuated by the serotonin uptake inhibitor citalopram. Neuropsychopharmacology 22:513-521.

Lindemann L, Hoener MC (2005) A renaissance in trace amines inspired by a novel GPCR family. Trends Pharmacol Sci 26:274-281.

Lindemann L, Meyer CA, Jeanneau K, Bradaia A, Ozmen L, Bluethmann H, Bettler B, Wettstein JG, Borroni E, Moreau JL, Hoener MC (2008) Trace amine-associated receptor 1 modulates dopaminergic activity. J Pharmacol Exp Ther 324:948-956.

Lindgren N, Xu ZQ, Herrera-Marschitz M, Haycock J, Hökfelt T, Fisone G (2001) Dopamine $\mathrm{D}(2)$ receptors regulate tyrosine hydroxylase activity and phosphorylation at Ser40 in rat striatum. Eur J Neurosci 13:773-780.

Livak KJ, Schmittgen TD (2001) Analysis of relative gene expression data using real-time quantitative PCR and the 2(-Delta Delta $\mathrm{C}(\mathrm{T})$ ) method. Methods 25:402-408.

Maguire JJ, Parker WA, Foord SM, Bonner TI, Neubig RR, Davenport AP (2009) International Union of Pharmacology. LXXII. Recommendations for trace amine receptor nomenclature. Pharmacol Rev 61:1-8.

McGregor IS, Callaghan PD, Hunt GE (2008) From ultrasocial to antisocial: a role for oxytocin in the acute reinforcing effects and long-term adverse consequences of drug use? Br J Pharmacol 154:358-368. 
Mechan AO, Esteban B, O'Shea E, Elliott JM, Colado MI, Green AR (2002) The pharmacology of the acute hyperthermic response that follows administration of 3,4-methylenedioxymethamphetamine (MDMA, "ecstasy") to rats. Br J Pharmacol 135:170-180.

Millan MJ, Audinot V, Rivet JM, Gobert A, Vian J, Prost JF, Spedding M, Peglion JL (1994) S 14297, a novel selective ligand at cloned human dopamine D3 receptors, blocks 7-OH-DPAT-induced hypothermia in rats. Eur J Pharmacol 260:3-5.

Millan MJ, Newman-Tancredi A, Audinot V, Cussac D, Lejeune F, Nicolas JP, Cogé F, Galizzi JP, Boutin JA, Rivet JM, Dekeyne A, Gobert A (2000a) Agonist and antagonist actions of yohimbine as compared with fluparoxan at alpha(2)-adrenergic receptors (AR)s, serotonin (5-HT)(1A), 5-HT(1B), 5-HT(1D) and dopamine D(2) and D(3) receptors. Significance for the modulation of frontocortical monoaminergic transmission and depressive states. Synapse 35:79-95.

Millan MJ, Lejeune F, Gobert A (2000b) Reciprocal autoreceptor and heteroreceptor control of serotonergic, dopaminergic and noradrenergic transmission in the frontal cortex: relevance to the actions of antidepressant agents. J Psychopharmacol 14:114-138.

Millan MJ, Marin P, Bockaert J, Mannoury la Cour C (2008) Signaling at G-protein-coupled serotonin receptors: recent advances and future research directions. Trends Pharmacol Sci 29:454-464.

Mlinar B, Corradetti R (2003) Endogenous 5-HT, released by MDMA through serotonin transporter- and secretory vesicle-dependent mechanisms, reduces hippocampal excitatory synaptic transmission by preferential activation of 5-HT1B receptors located on CA1 pyramidal neurons. Eur J Neurosci 18:1559-1571.

Panas HN, Lynch LJ, Vallender EJ, Xie Z, Chen GL, Lynn SK, Scanlan TS, Miller GM (2010) Normal thermoregulatory responses to 3-iodothyronamine, trace amines and amphetamine-like psychostimulants in trace amine associated receptor 1 knockout mice. J Neurosci Res 88:1962-1969.

Ramamoorthy S, Samuvel DJ, Buck ER, Rudnick G, Jayanthi LD (2007) Phosphorylation of threonine residue 276 is required for acute regulation of serotonin transporter by cyclic GMP. J Biol Chem 282:11639-11647.

Rodsiri R, Spicer C, Green AR, Marsden CA, Fone KCF (2011) Acute concomitant effects of MDMA binge dosing on extracellular 5-HT, locomotion and body temperature and the long-term effect on novel object discrimination in rats. Psychopharmacology (Berl) 213:365-376.

Rudnick G, Wall SC (1992) The molecular mechanism of "ecstasy" [3,4- methylenedioxy-methamphetamine (MDMA)]: serotonin transporters are targets for MDMA-induced serotonin release. Proc Natl Acad Sci U S A 89:1817-1821.

Scanlan TS, Suchland KL, Hart ME, Chiellini G, Huang Y, Kruzich PJ, Frascarelli S, Crossley DA, Bunzow JR, Ronca-Testoni S, Lin ET, Hatton D, Zucchi R, Grandy DK (2004) 3-Iodothyronamine is an endogenous and rapid-acting derivative of thyroid hormone. Nat Med 10:638-642.

Schifano F (2004) A bitter pill. Overview of ecstasy (MDMA, MDA) related fatalities. Psychopharmacology (Berl) 173:242-248.

Sotnikova TD, Zorina OI, Ghisi V, Caron MG, Gainetdinov RR (2008) Trace amine associated receptor 1 and movement control. Parkinsonism Relat Disord 14 [Suppl 2]:S99-S102.

Stalder H, Hoener MC, Norcross RD (2011) Selective antagonists of mouse trace amine-associated receptor 1 (mTAAR1): discovery of EPPTB (RO5212773). Bioorg Med Chem Lett 21:1227-1231.

Svenningsson P, Chergui K, Rachleff I, Flajolet M, Zhang X, El Yacoubi M, Vaugeois JM, Nomikos GG, Greengard P (2006) Alterations in 5-HT1B receptor function by p11 in depression-like states. Science 311:77-80.

Vollenweider FX, Remensberger S, Hell D, Geyer MA (1999) Opposite effects of 3,4-methylenedioxymethamphetamine (MDMA) on sensorimotor gating in rats versus healthy humans. Psychopharmacology (Berl) 143:365-372.

Vollenweider FX, Liechti ME, Gamma A, Greer G, Geyer M (2002) Acute psychological and neurophysiological effects of MDMA in humans. J Psychoactive Drugs 34:171-184.

Wolinsky TD, Swanson CJ, Smith KE, Zhong H, Borowsky B, Seeman P, Branchek T, Gerald CP (2007) The Trace Amine 1 receptor knockout mouse: an animal model with relevance to schizophrenia. Genes Brain Behav 6:628-639.

Xie Z, Miller GM (2007) Trace amine-associated receptor 1 is a modulator of the dopamine transporter. J Pharmacol Exp Ther 321:128-136.

Xie Z, Miller GM (2008) Beta-phenylethylamine alters monoamine transporter function via trace amine-associated receptor 1: implication for modulatory roles of trace amines in brain. J Pharmacol Exp Ther 325:617-628

Xie Z, Westmoreland SV, Miller GM (2008) Modulation of monoamine transporters by common biogenic amines via trace amine-associated receptor 1 and monoamine autoreceptors in human embryonic kidney 293 cells and brain synaptosomes. J Pharmacol Exp Ther 325:629-640. 